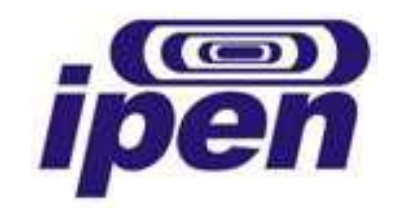

INSTITUTO DE PESQUISAS ENERGÉTICAS E NUCLEARES

Autarquia associada à Universidade de São Paulo

\begin{abstract}
GRAXA DE POLIURÉIA - ESTUDO DA COMPATIBILIDADE DA POLIURÉIA, POLIALFAOLEFINA E POLITETRAFLUORETILENO IRRADIADO PARA MELHORIA DA LUBRICIDADE E ESTABILIDADE
\end{abstract}

NATALIA TORRES RATÃO

Dissertação apresentada como parte dos requisitos para obtenção do Grau de Mestre em Ciências na Área de Tecnologia Nuclear - Materiais

Orientador:

Prof. Dr. Ademar Benévolo Lugão

SÃO PAULO

2013 
Dedico este trabalho aos meus pais, Nelio e Sandra, pelo apoio, cuidado e compreensão, sou grata a eles por tudo o que me tornei e conquistei, e também ao meu marido Ricardo que me deu todo suporte e amor durante todo o processo. 


\section{AGRADECIMENTOS}

Em primeiro lugar a Deus que me permitiu vivenciar essa experiência gratificante, me sustenta a cada dia com seu amor, cuidado e misericórdia.

Aos meus pais, Nelio e Sandra, com todo o meu amor por me ensinarem principalmente o caminho do Senhor e me ajudarem a trilhar o caminho do conhecimento, do trabalho e das conquistas próprias, sempre me dando o exemplo de caráter e amor. Serei eternamente grata a vocês por tudo o que sou!

Ao meu marido, Ricardo, pelo apoio, incentivo, suporte e todo amor. Sou grata por sempre ter uma palavra de conforto e ânimo, por somente me dar alegrias e sempre estar pronto a me ajudar.

Ao meu orientador Dr. Ademar Benévolo Lugão, primeiramente por ter me aceitado como aluna, me dando a oportunidade de ampliar meus conhecimentos. Sou grata

pela paciência em ensinar, pela prontidão em atender, por ter confiado em meu trabalho e por mostrar prazer em transmitir seu amplo conhecimento. Meus sinceros agradecimentos, pois foi um prazer ter trabalho ao seu lado.

À querida Heloisa Augusto Zen, por estar sempre a postos para ajudar, explicar e ensinar. Muito obrigada por ser essa pessoa maravilhosa, uma excelente profissional e amiga. Sua ajuda foi essencial e muito preciosa! Obrigada por tudo!

À todos pesquisadores do laboratório de polímeros do CQMA, que de alguma forma contribuíram para realização deste trabalho, aos meus colegas Clarissa Dias, Caroline Ferraz, Leonardo Marchini, Liana Nakamura, Débora Salum, Elen Gonçalves Brasil e Klauss Engelmann, pela ajuda, carinho e incentivo. Aos Engenheiros Flavio Augusto Torres e Rafael de Lima Soares, por terem contribuído muito com a minha pesquisa, por me substituírem enquanto estive ausente no trabalho, por terem sido parceiros e verdadeiros amigos. Muito obrigada por todo apoio, companheirismo, amizade e carinho ao longo deste trabalho. 
À toda minha família que sempre me apoiou, as minhas irmãs Elizabeth Torres e Ligia Luisa Torres, aos meus sobrinhos que tanto amo, a minha prima Patrícia Torres Villar que é um exemplo de determinação e principalmente aos meus sogros Nadia e Wilson que demonstram tanto amor, carinho e cuidado por mim.

Aos meus irmãos em Cristo da Igreja Batista em Planalto Paulista que me cercaram de oração, me apoiaram e me incentivaram, ao meu pastor Marcos Petriaggi por todo amor, acolhimento e oração, as minhas amigas Priscila e Flavia que muitas vezes me escutaram, aconselharam e compartilharam das minhas dificuldades e a liderança feminina Neide Fidelis e Marilza Leite pelo apoio espiritual e amizade.

À empresa Maxioil do Brasil que me apoiou durante todo o trabalho, me deu suporte laboratorial, materiais, apoio intelectual e principalmente acreditou que eu era capaz.

Que Deus sempre abençoe os caminhos da Maxioil e que ela seja símbolo de trabalho e conquistas.

À Universidade de São Paulo pela oportunidade de realizar este trabalho, pela estrutura e profissionais de primeira.

Ao IPEN por toda infra-estrutura, pelos serviços oferecidos e por selecionar pessoas realmente comprometidas com a pesquisa. 
"O conselho da sabedoria é: procure obter sabedoria; use tudo que você possui para adquirir entendimento."

Provérbios 4 


\title{
GRAXA DE POLIURÉIA - ESTUDO DA COMPATIBILIDADE DA POLIURÉIA, POLIALFAOLEFINA E POLITETRAFLUORETILENO IRRADIADO PARA MELHORIA DA LUBRICIDADE E ESTABILIDADE
}

\author{
Natalia Torres
}

RESUMO

Lubrificantes são produtos gasosos, líquidos, semi sólidos ou sólidos (pó) que formam um filme entre duas partes evitando o atrito. Lubrificantes de alto desempenho são designados para trabalharem em condições severas de temperatura, pressão e contaminação. Os mais utilizados são os líquidos (óleos) e semi sólidos (graxas). As graxas são aplicadas aonde o óleo pode escorrer e em pontos de difícil acesso e são divididas basicamente em duas classes, sabão e não sabão. A graxa não sabão mais utilizada é a poliuréia, obtida pela reação entre aminas e isocianato, possui elevada tixotropia, alta rigidez dielétrica e excelente poder anticorrosivo, por isso é amplamente utilizada para lubrificação de motores elétricos e maquinário naval. Para obter uma graxa com altíssimo desempenho, nesse estudo foi utilizado o fluido lubrificante sintético polialfaolefina e também foi empregado o aditivo lubrificante sólido politetrafluoroetileno (PTFE) por apresentar o menor coeficiente de atrito conhecido, é comercialmente encontrado irradiado em ar para obter partículas menores e produzir grupos terminais oxigenados que são mais compatíveis com a superfície metálica. Os ensaios foram realizados de forma comparativa usando a graxa de poliuréia pura e aditivada com PTFE. As caracterizações foram feitas por espectroscopia de infravermelho, análise elementar de $\mathrm{C}, \mathrm{N}$, e H e índice de NCO livre, comprovando a formação de poliuréia de quatro carbonos (tetrauréia). As propriedades funcionais de ponto de gota e separação de óleo mostraram alta compatibilidade e estabilidade entre os polímeros, que aumentaram quando foi adicionado PTFE. A excelente resistência da graxa de tetrauréia pura ao desgaste e extrema pressão foram demonstradas pelo teste de quatro esferas e teste prático em rolamentos, caracterizando esta graxa como de alto desempenho quando comparada com as graxas mais utilizadas no mercado.

Palavras-chave: Lubrificante, Graxa, Poliuréia (PUR), Polialfaolefina (PAO), Politetrafluoretileno (PTFE) e Radiação Ionizante. 


\title{
DEVELOPMENT OF HIGH PERFORMANCE LUBRICANT THROUGH THE COMPATIBILITY OF POLYALPHAOLEFIN, POLYUREA AND IRRADIATED POLYTETRAFLUOROETHYLENE
}

\begin{abstract}
Natalia Torres
ABSTRACT

Lubricants are gaseous, liquid, semi solid or solid (powder) materials those form a film between two parties preventing friction. High performance lubricants are designed to work under severe conditions of temperature, pressure, and contamination. The most used are liquids (oils) and semi solids (greases). Greases are applied where oils can drain or in inaccessible places and are divided generally into two classes, soap and no soap. The most used non soap grease is polyurea, obtained by the reaction between amine and isocyanate, has highly thixotropic, high dielectric strength and excellent anticorrosive property, so it is widely used for lubrication of electric motors and shipbuilding machinery. For a grease with high performance, in this study was used a synthetic lubricant fluid, polyalphaolefin, and was also employed solid lubricant additive polytetrafluoroethylene (PTFE) due its lowest coefficient of friction, is found commercially irradiated in air to obtain smaller particles and to produce oxygenated terminal groups those are more compatible with the metal surface. The tests conducted were comparatively between pure polyurea grease and with PTFE additive. The characterizations were made by infrared spectroscopy and elemental analysis of $\mathrm{C}, \mathrm{N}$ and $\mathrm{H}$ and Free NCO index, proving the formation of four carbons polyurea (tetraurea). The functional analysis of drop point and oil separation showed high stability and compatibility between the polymers increased when PTFE was added. The excellent resistance of pure tetraurea grease to wear and extreme pressure were demonstrated by four-ball and practical bearings tests, characterizing this grease as a high performance lubricant, when compared to most used greases in the market.
\end{abstract}

Key-words: Lubricant, Grease, Polyurea (PUR), polyalphaolefin (PAO), polytetrafluoroethylene (PTFE) and lonizing Radiation. 


\section{SUMÁRIO}

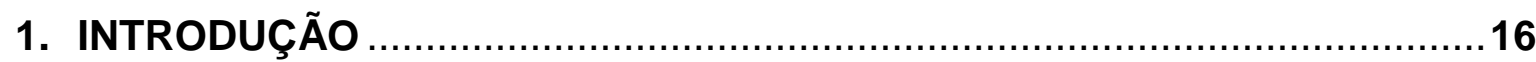

2. OBJETIVOS

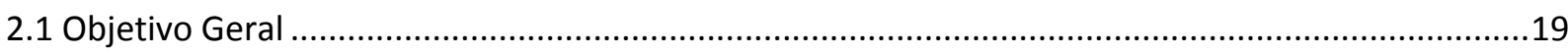

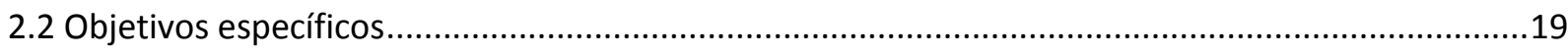

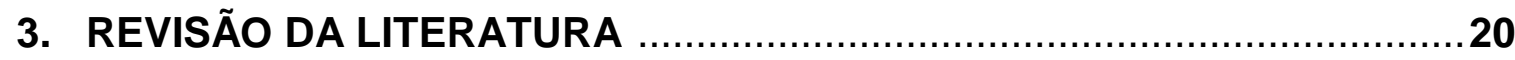

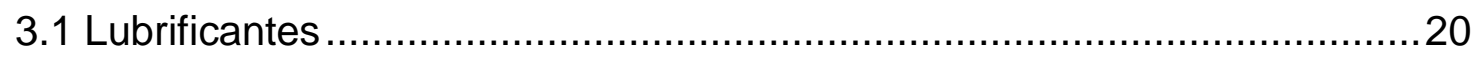

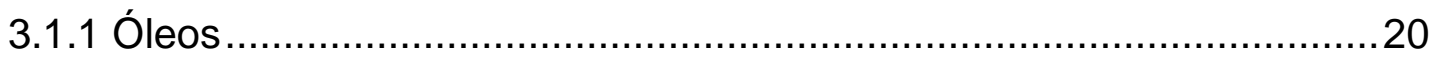

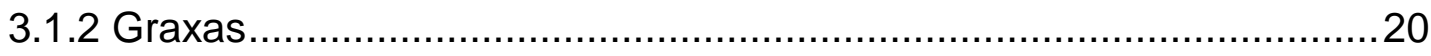

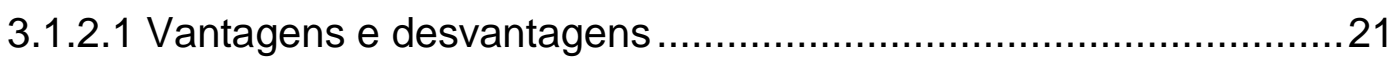

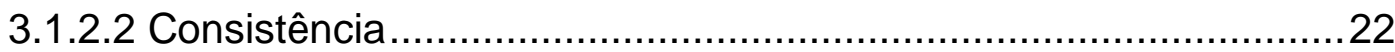

3.2 Graxas lubrificantes - Composição...................................................24

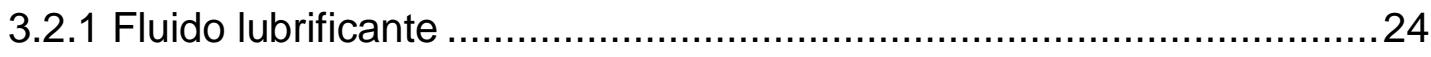

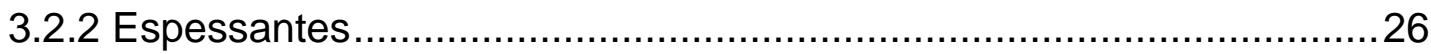

3.2.2.1 Espessantes à base de sabão metálico .....................................26

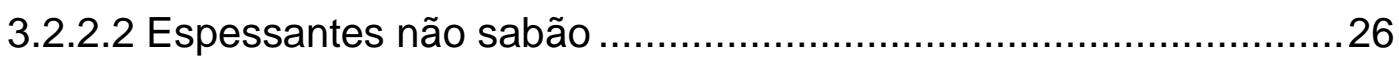

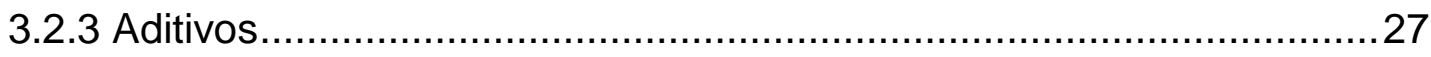

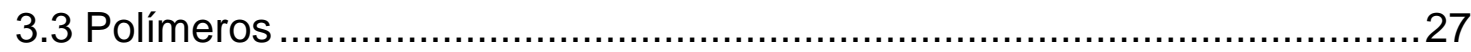

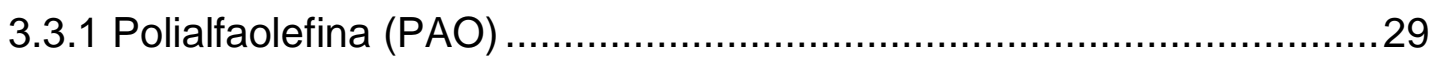

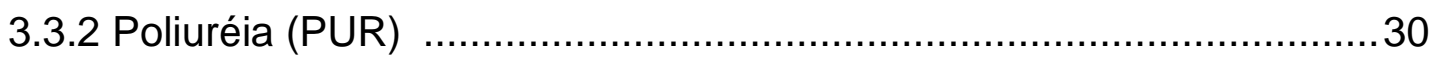

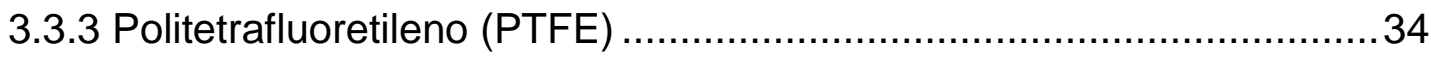

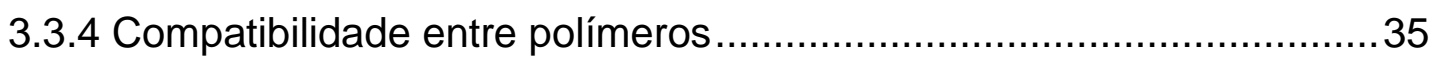

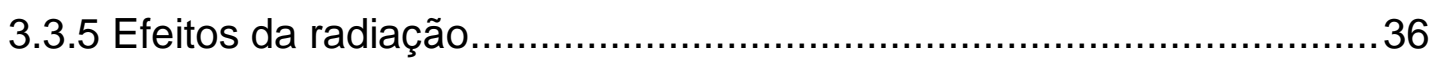

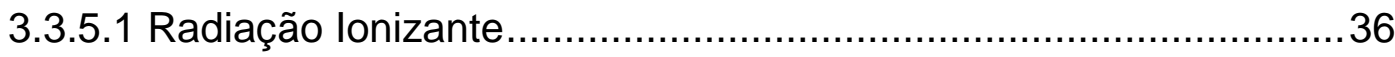

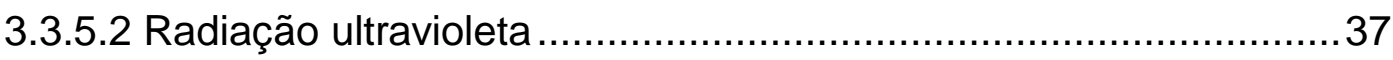

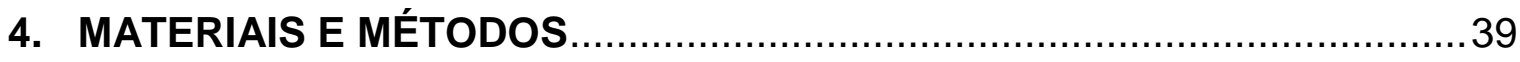

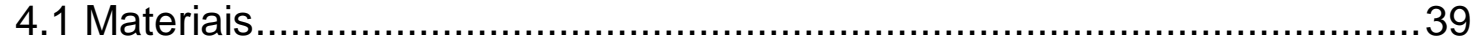

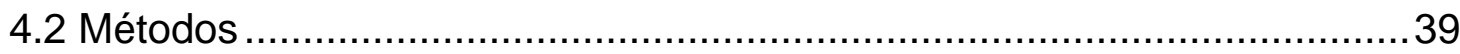




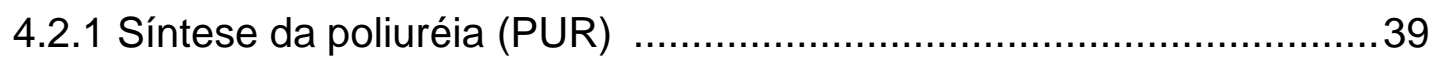

4.2.2 Adição de Politetrafluoretileno (PTFE) irradiado .................................41

4.2.3 Índice de NCO livre ...................................................................... 41

4.2.4 Espectroscopia de Absorção no Infravermelho por Transformada de

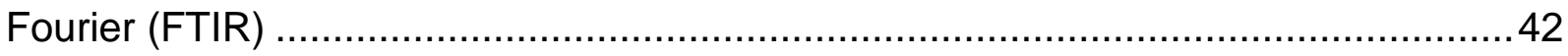

4.2.5 Análise elementar ............................................................... 42

4.2.6 Microscopia eletrônica de varredura (MEV) ...................................42

4.2.7 Calorimetria exploratória diferencial (DSC) ......................................43

4.2.8 Estudo da temperatura de gota da graxa....................................... 43

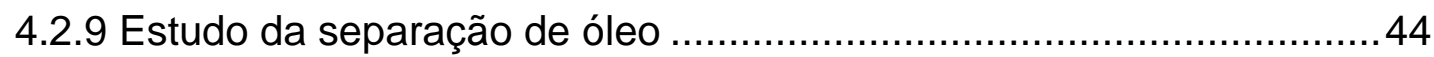

4.2.10 Estudo de penetração não trabalhada e trabalhada .........................44

4.2.11 Estudo das características de extrema pressão e antidesgaste por

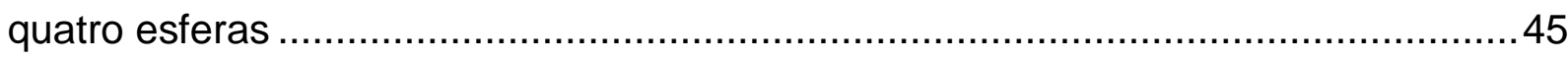

4.2.12 Estudo do desempenho de graxas em rolamentos .........................46

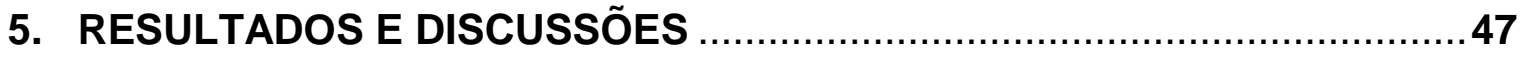

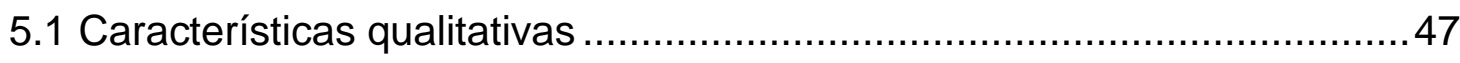

5.1.1 Síntese da tetrauréia em polialfaolefina .........................................4 4

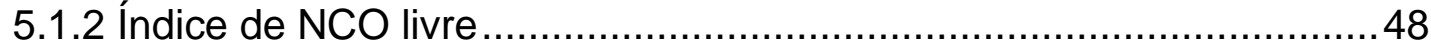

5.1.3 Espectroscopia de infravermelho com transformada de Fourrier (FTIR) 49

5.1.4 Análise Elementar (AE) ........................................................53

5.1.5 Microscopia eletrônica de varredura (MEV) ...................................54

5.1.6 Calorimetria Exploratória Diferencial (DSC) ...................................60

5.2 Estudo das características funcionais da graxa de tetrauréia ....................61

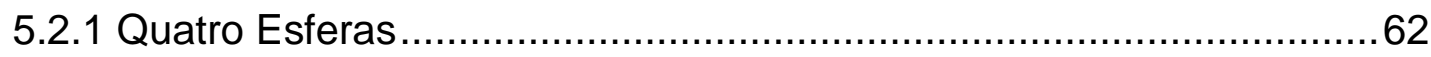

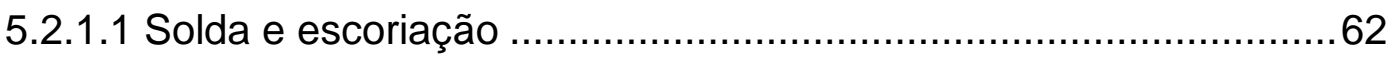

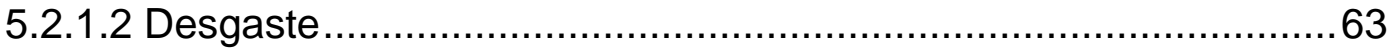

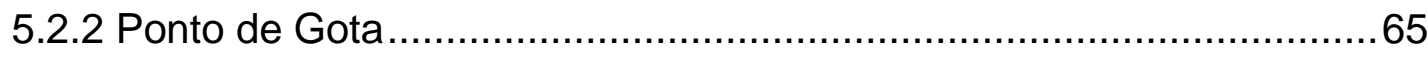

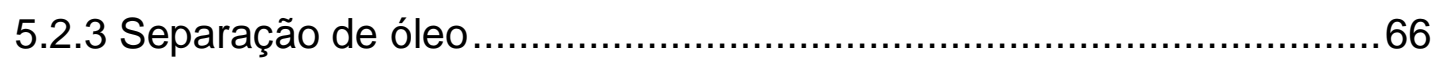

5.2.4 Determinação da consistência pela penetração do cone .....................66

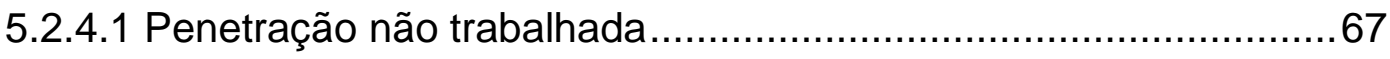




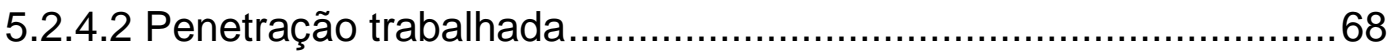

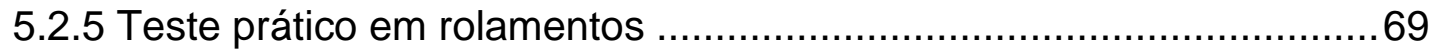

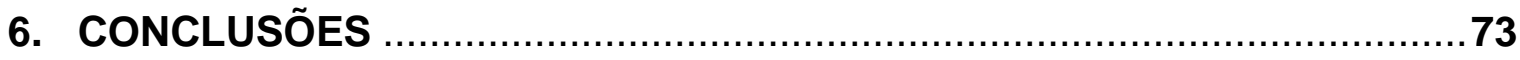

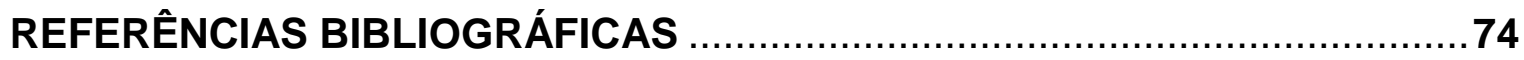




\section{Lista de Tabelas}

TABELA 1. Classificação da consistência de graxas de acordo com a penetração trabalhada. .24

TABELA 2. Características de algumas ligações covalentes. 28

TABELA 3. Velocidade relativa de reações típicas dos isocianatos não catalisada a $25^{\circ} \mathrm{C}$. 32

TABELA 4. Isocianatos comerciais. .33

TABELA 5. Resultados das reações entre diversos tipos de aminas e TDI. 47

TABELA 6. Resultados da análise de NCO livre na amostra da graxa. .48

TABELA 7.Resultados da análise elementar do pó de tetrauréia obtido em solvente xileno e isento de PTFE. .53

TABELA 8. Resultados da análise elementar do pó de tetrauréia retirado da graxa base por lavagem com hexano .54

TABELA 9. Resultados da análise de DSC nas amostras de PTFE 61

TABELA 10. Resultados do ensaio de quatro esferas - solda na graxa pura, aditivada com PTFE processado por radiação iniozante e ultravioleta 62

TABELA 11. Resultados do ensaio de quatro esferas - desgaste com a graxa de tetrauréia pura e aditivada com PTFE processado por radiação ionizante e ultravioleta. .63

TABELA 12. Resultados do ensaio de quatro esferas - desgaste em graxas de lítio, cálcio e diuréia 64

TABELA 13. Resultados do ensaio de ponto de gota na graxa de tetrauréia pura e aditivada com PTFE de $4 \mu$.

TABELA 14. Resultados do ensaio de separação de óleo na graxa de tetrauréia pura e aditivada com PTFE. 66

TABELA 15. Classificação NLGI para consistência de graxas lubrificantes. 67

TABELA 16. Valores de penetração não trabalhada da graxa de tetrauréia. 67

TABELA 17. Resultado de penetração da graxa de tetrauréia aditivada com PTFE trabalhada 10.000 vezes. 


\section{Lista de Figuras}

FIGURA 1. Aplicação de graxas lubrificantes em engrenagens..............................22

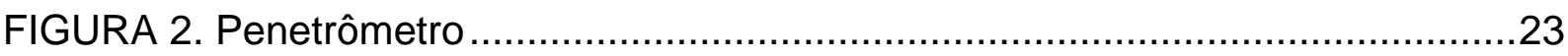

FIGURA 3. Representação esquemática da classificação de um polímero quanto à natureza de suas ligações e sua estrutura............................................................29

FIGURA 4. Representação química da estrutura da molécula de polialfaolefina ........30

FIGURA 5. Representação das possíveis reações químicas dos isocianatos ............31

FIGURA 6. Representação da polimerização do politetrafluoroetileno ......................34

FIGURA 7. Reação de síntese da tetrauréia em polialfaolefina a $60^{\circ} \mathrm{C}$......................40

FIGURA 8. Ilustração do arranjo experimental para a síntese de poliuréia ................40

FIGURA 9. Ilustração da hélice do reator utilizada na síntese da poliuréia ...............40

FIGURA 10. Ilustração do moinho de três rolos para processamento de graxas lubrificantes

FIGURA 11. Ilustração da análise de ponto de gota de graxa lubrificante. 43

FIGURA 12. Instrumento para análise de separação de óleo da graxa .44

FIGURA 13. Análise de penetração da graxa

FIGURA 14. a)llustração do equipamento de quatro esferas "Four Ball" e b) esferas soldadas após o teste.

FIGURA 15. Fotografia da graxa de poliuréia após a reação

FIGURA 16. Espectro de FTIR-ATR da graxa de tetrauréia em comparativo com a tetrauréia pura em pó.

FIGURA 17. Espectros de FTIR-ATR comparativos entre a dodecilamina, etilenodiamina, TDI e a graxa .50

FIGURA 18. Espectros de FTIR-ATR do fluido PAO em comparativo com a graxa de tetrauréia .51

FIGURA 19. Espectros de FTIR-ATR comparativos entre o PTFE virgem, PTFE irradiado por ultravioleta e por radiação ionizante.

FIGURA 20. Micrografias da amostra a) graxa de tetrauréia aditivada com PTFE de $4 \mu$ com aumento de 500,1000 e 5000 vezes 
FIGURA 21. Micrografias ampliadas 500, 1000 e 5000 vezes da amostra b) pó de tetrauréia retirada da graxa obtida em polialfaolefina (isenta de PTFE) através da

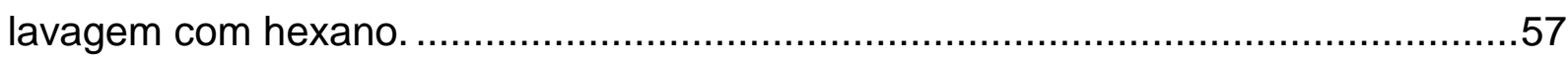

FIGURA 22. Micrografias da amostra c) pó da tetrauréia obtido diretamente em solvente xileno (isento de PTFE) ampliadas 500, 1000 e 5000 vezes .......................59 FIGURA 23. Trabalhador automático de graxa lubrificante para análise de penetração

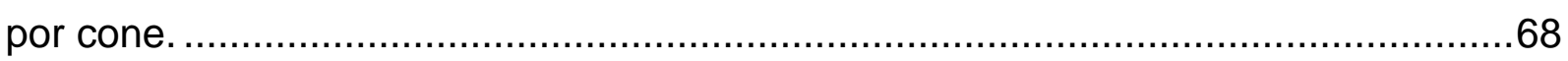

FIGURA 24. Fotografias da montagem do teste de rolamentos.............................70

FIGURA 25. Fotografias dos rolamentos após 24 horas de teste.............................71

FIGURA 26. Fotografias dos rolamentos após 72 horas de teste............................72 


\section{Lista de Abreviaturas}

ABNT - Assosiação Brasileira de Normas Técnicas

ASTM - American Society for Testing and Materials

ATR - Refletância Total Atenuada

DSC - Calorimetria Exploratória Diferencial

FTIR - Espectroscopia de infravermelho por transformada de Fourier

MEV - Microscópio Eletrônico de Varredura

NLGI - National Lubricating Grease Institute - Instituto Nacional de Graxa Lubrificante

PUR - Poliuréia

PAO - Polialfaolefina

SINDICOM - Sindicato Nacional das Empresas Distribuidoras de Combustíveis e de Lubrificantes

TDI - Tolueno diisocianato

UV - Ultravioleta 


\title{
Lista de Unidades
}

\author{
cm - centímetro \\ cSt - Centistokes \\ $\mathbf{g} / \mathbf{c m}^{3}$ - gramas/centímetro cúbico \\ Kg - quilograma \\ MeV - Megaelétron-volt \\ mm/10 - décimo de milímetro \\ rpm - rotações por minuto \\ $\%$ - porcentagem \\ $\mu \mathrm{m}$ - micrometro \\ ㅇ - graus Celsius
}




\section{INTRODUÇÃO}

Os primeiros lubrificantes foram desenvolvidos pelo povo egípcio em torno de 1.700 a.C., eles costumavam usar água, lama, resíduos de gordura animal e vegetal para arrastarem seus trenós, mas só após o século 18 que os produtos de petróleo foram melhores explorados, refinados e aplicados (CARRETEIRO; MOURA, 1998). Hoje os lubrificantes têm grande importância nas indústrias, não só para manterem o processo funcionando continuamente, mas para evitarem excesso de manutenções, quebra de máquinas, gastos excessivos, mau acabamento e desperdícios de produtos.

O princípio básico da lubrificação é sempre que um corpo ou fluido movese sobre a superfície de outro originando uma força contrária ao movimento, chamada força de atrito. O atrito dificulta o movimento, consome energia sem produzir correspondente trabalho e promove desgaste. O lubrificante tem a função de formar um filme entre as partes, a fim de reduzir o atrito ao mínimo e evitar os problemas resultantes, como o desgaste excessivo, mau acabamento, aquecimento do sistema, quebra de equipamentos, entre outros. Os lubrificantes podem ser líquidos, semi-sólidos (graxas) ou em casos muito específicos, sólidos secos (CRUZ; SOUZA, 1982).

A fabricação anual de graxas lubrificantes no mundo que em 2005 era de 250 milhões de quilos, segundo dados do National Lubricanting Grease Institute (NLGI), bateu o recorde em 2011 chegando a quase 1,1 bilhão de quilos. No Brasil, segundo dados mais recentes do Sindicato Nacional das Empresas Distribuidoras de Combustíveis e de Lubrificantes (SINDICOM, 2012) o comércio de graxas lubrificantes ultrapassou a marca de 45 milhões de quilos, ressaltando a importância de novos desenvolvimentos de lubrificantes mais específicos e com melhor custobenefício.

As graxas são utilizadas nos pontos onde os óleos não são eficazes em face da sua tendência natural de escorrerem, por mais viscosos que sejam. As principais vantagens das graxas em relação aos óleos são: selagem e isolamento do 
ponto lubrificado, maior adesividade, maior tempo de uso e utilização em locais de difícil acesso (CARRETEIRO; MOURA, 1998). As principais desvantagens são quanto às limitações em altas velocidades em função do maior atrito do fluido, menor resistência à oxidação e menor poder refrigerante (PIRES, 1975). A principal diferença entre o lubrificante líquido e semi-sólido é que a graxa possui espessante (CARRETEIRO; BELMIRO, 2006).

O espessante pode ser definido como um agente modificador da estrutura do fluido lubrificante fazendo com que este obtenha consistência. A consistência da graxa varia de acordo com a porcentagem e com o tipo de espessante utilizado. A natureza química e concentração do espessante conferem as graxas determinadas características como: ponto de gota, estrutura, comportamento na presença de água e resistência a temperaturas elevadas (LUBARSA, 1970). Os espessantes são divididos em dois tipos: sabão e não-sabão. Espessantes nãosabão são compostos inorgânicos ou orgânicos que são insolúveis dentro do fluido lubrificante, porém são capazes de estabilizar-se no óleo em razão da sua estrutura superficial porosa (MOTEURS, 1975). Os espessantes não-sabões mais utilizados são as poliuréias (PUR), bentonitas, gel de sílica e plásticos como o politetrafluoretileno (PTFE) e o polietileno (PE) (RUNGE, 1994).

As poliuréias são formadas por reações de isocianatos com aminas, essas reações são muito rápidas e não necessitam de catálise (VILAR, 2004). A graxa espessada com poliuréia é amplamente utilizada para lubrificar motores elétricos, por ter alta rigidez dielétrica ou para pontos expostos a umidade ou maresia, pois apresenta excelente característica anticorrosiva. Uma desvantagem da graxa espessada com poliuréia é a sua tixotropia elevada, quando em repouso a graxa sofre variação de consistência, ou seja, endurece ou amolece, quando comparado em trabalho, interferindo no filme lubrificante, o que consequentemente aumenta $o$ atrito, por esse motivo não são indicadas para sistemas centralizados.

Também podem ser adicionados às graxas, aditivos, que são compostos que conferem aos lubrificantes propriedades especiais ausentes ou presentes em grau insuficiente no óleo puro (HISSA, 1991). Alguns exemplos são: aditivos antidesgaste, de extrema pressão, antioxidantes e de lubricidade. O PTFE é 
amplamente utilizado como aditivo de lubricidade por ser o material com o menor coeficiente de atrito já conhecido. Em geral ele é utilizado irradiado para se trabalhar com partículas menores que por sua vez conseguem penetrar melhor nos poros das superfícies, tornando-as mais lisas, ou seja, facilitando o movimento.

Graxas de alto desempenho são produzidas comumente com óleos sintéticos, espessantes não sabão, por serem mais resistentes a temperatura e aditivadas com lubrificante sólido. Desta forma foram estudados diversos tipos e combinações de aminas para a obtenção de uma tetrauréia especial, dispersa em um fluido sintético com elevada estabilidade térmica e aditivada com PTFE, com o objetivo de superar o desempenho das graxas mais utilizadas no mercado, em condições extremas, nos quesitos lubricidade, resistência térmica e maior estabilidade. 


\section{OBJETIVOS}

\subsection{Objetivo geral}

Melhorar a compatibilidade da polialfaolefina (PAO) com a poliuréia (PUR) e o politetrafluoretileno (PTFE) por meio da síntese de poliuréias com estruturas diferentes e funcionalização do PTFE para o desenvolvimento de uma graxa lubrificante com excelente estabilidade e lubricidade.

\subsection{Objetivos específicos}

- Sintetizar uma graxa à base de poliuréia;

- Caracterizar a poliuréia obtida;

- Avaliar a eficiência da graxa de poliuréia pura;

- Avaliar a melhoria das propriedades físico químicas e funcionais da graxa de poliuréia com a adição do aditivo lubrificante politetrafluoretileno (PTFE) irradiado;

- Avaliar a aplicabilidade da graxa obtida no mercado industrial; 


\section{REVISÃO DA LITERATURA}

\subsection{Lubrificantes}

Lubrificantes são substâncias gasosas, líquidas, graxosas ou sólidas designadas para formarem uma película que impede o contato direto entre duas superfícies que se movem uma sobre a outra, com isso o atrito é reduzido a níveis mínimos quando comparado ao contato direto, exigindo uma força menor para a realização do trabalho, evitando o desgaste dos corpos e diminuindo o consumo energético (CARRETEIRO; MOURA, 1998). Existe uma grande variedade de produtos lubrificantes, entre eles têm-se os mais importantes: óleos e graxas.

\subsection{1Óleos}

Comumente são encontrados três tipos de óleos: os minerais, obtidos a partir do petróleo e consequentemente relacionam-se à natureza do óleo cru com composição variada, formada por grande número de hidrocarbonetos, sendo que os mais utilizados são de série parafínica (alcanos), naftênica (cicloparafinas) e aromática, os óleos graxos de origem vegetal ou animal, ricos em ácidos graxos e cadeias mono e poliinsaturada e os óleos sintéticos, criados em laboratório por processos de síntese ou polimerização, especialmente desenvolvidos para oferecer características especiais de viscosidade e resistência a temperaturas extremas, de forma a atender aplicações específicas de algumas indústrias (HISSA, 1991).

\subsubsection{Graxas}

Segundo o Instituto Francês do Petróleo (1984), a definição mais utilizada de graxa lubrificante é a publicada pela American Society for Testing and Materials ASTM D 288-61, a qual diz que uma graxa lubrificante é um produto de consistência semi-fluido a sólido, obtido por dispersão de um agente espessante em meio a um fluido lubrificante. Para alcançar certas propriedades especiais, produtos de adição, ou seja, aditivos podem ser inclusos (MOTEURS, 1985). 
Para obter uma estrutura semi-sólida de uma graxa, é necessário que as partículas elementares do agente espessante formem uma rede tridimensional coerente, com estabelecimento de forças de ligações internas. Não se pode confundir graxas lubrificantes com produtos espessados, colocados em grupos que se chamam pastas lubrificantes, obtidos por simples dispersão mecânica de um sólido pulverizado (grafite, bissulfeto de molibdênio e outros) dentro de um fluido sem a formação de rede tridimensional homogênea ou estabelecimento das forças de ligações internas (MOTEURS, 1975). Esse tipo de produto mostra geralmente uma instabilidade estrutural caracterizada por uma tendência marcada na separação da fase líquida, que é devido à migração do óleo para a superfície do produto.

No caso das graxas, o agente espessante é insolúvel no fluido lubrificante e cria um sistema disperso do tipo coloidal (mistura heterogênea composta por agente dispersante e agente disperso, que equivalem respectivamente ao fluido lubrificante e espessantes). A estabilidade da suspensão do espessante depende de quatro principais parâmetros: concentração do agente espessante, dimensões elementares do espessante, poder solvente do fluido lubrificante e das forças de atração entre as partículas do espessante e a cadeia do fluido que permitem manter o sistema em equilíbrio, a natureza dessas forças varia de acordo com o tipo químico do espessante utilizado, por exemplo, pontes de hidrogênio e forças de Van der Waals (MOTEURS, 1975), assim como o arranjo de sua estrutura molecular.

\subsubsection{Vantagens e desvantagens}

As graxas são utilizadas nos pontos onde os óleos não seriam eficazes em face de sua tendência natural de escorrer, por mais viscoso que seja. As principais vantagens em relação aos óleos são: selagem e isolamento do ponto lubrificado, maior adesividade do lubrificante, maior vida útil e utilização em locais de difícil acesso.

Em mancais de rolamentos a sua utilização é devido à boa retenção do lubrificante, lubrificação instantânea na partida do equipamento, mínimo vazamento através das vedações, elimina contaminação de impurezas, permite várias posições nas operações (vertical e horizontal) e requerem aplicações menos freqüentes 
quanto à relubrificação. Em mancais de deslizamento sua utilização é devido à boa retenção do lubrificante e resistência ao choque mecânico devido ao movimento. Em engrenagens sua utilização é devido à boa retenção em engrenagens abertas, como mostrada na figura a seguir, resistência à ação de remoção imposta pela força centrífuga da engrenagem e resistência a pressão de carga imposta pelo trabalho da engrenagem (Naka; Koizumi; Takahashi; Goto; Endo; Suzuki, 1996).

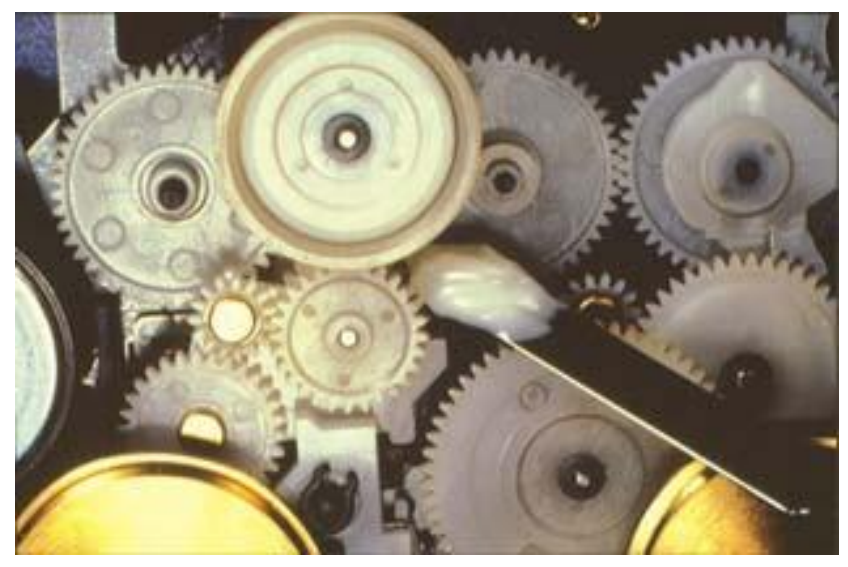

FIGURA 1. Aplicação de graxas lubrificantes em engrenagens (Fonte: Revista "Química e Derivados" - Edição no 421 de novembro 2003).

As principais desvantagens são quanto às limitações a altas velocidades em função do maior atrito do fluido, menor resistência à oxidação e menor poder refrigerante (PIRES, 1975).

\subsubsection{Consistência}

A consistência através do teste de penetração "trabalhada" ou "não trabalhada" é determinada empiricamente medindo a distância que um cone, de dimensões e peso padronizados, penetra na graxa sob determinadas condições, este método segue a norma ASTM D 217-52T, demonstrado na figura 2.

No caso de graxas muito consistentes ou duras, que não permitem realizar leituras usando-se o cone, usam-se agulhas padronizadas. Para as graxas pouco consistentes ou mais fluidas, substitui-se o cone de aço ou latão por um de alumínio ou plástico, por serem menos densos. A penetração é expressa em décimos de milímetro e a leitura é feita após o cone permanecer em contato com a graxa durante 5 segundos, a temperatura padronizada de $298,15 \mathrm{~K}\left(25^{\circ} \mathrm{C}\right)$. 
A penetração não trabalhada da graxa é feita retirando-a do recipiente onde se encontra e aplicando o teste de consistência, devendo sua temperatura ser previamente ajustada a $298,15 \mathrm{~K}\left(25^{\circ} \mathrm{C}\right)$. Na penetração trabalhada a graxa é previamente submetida a movimentos que simulam o trabalho prático da graxa, causando cisalhamento, esses movimentos são realizados em um aparelho ou dispositivo padrão denominado "trabalhador de graxa" e depois a análise de penetração é realizada no mesmo equipamento da não trabalhada. Assim pode-se avaliar a variação de consistência da graxa quando em serviço (CARRETEIRO; MOURA, 1998).

\section{Penetrômetro}

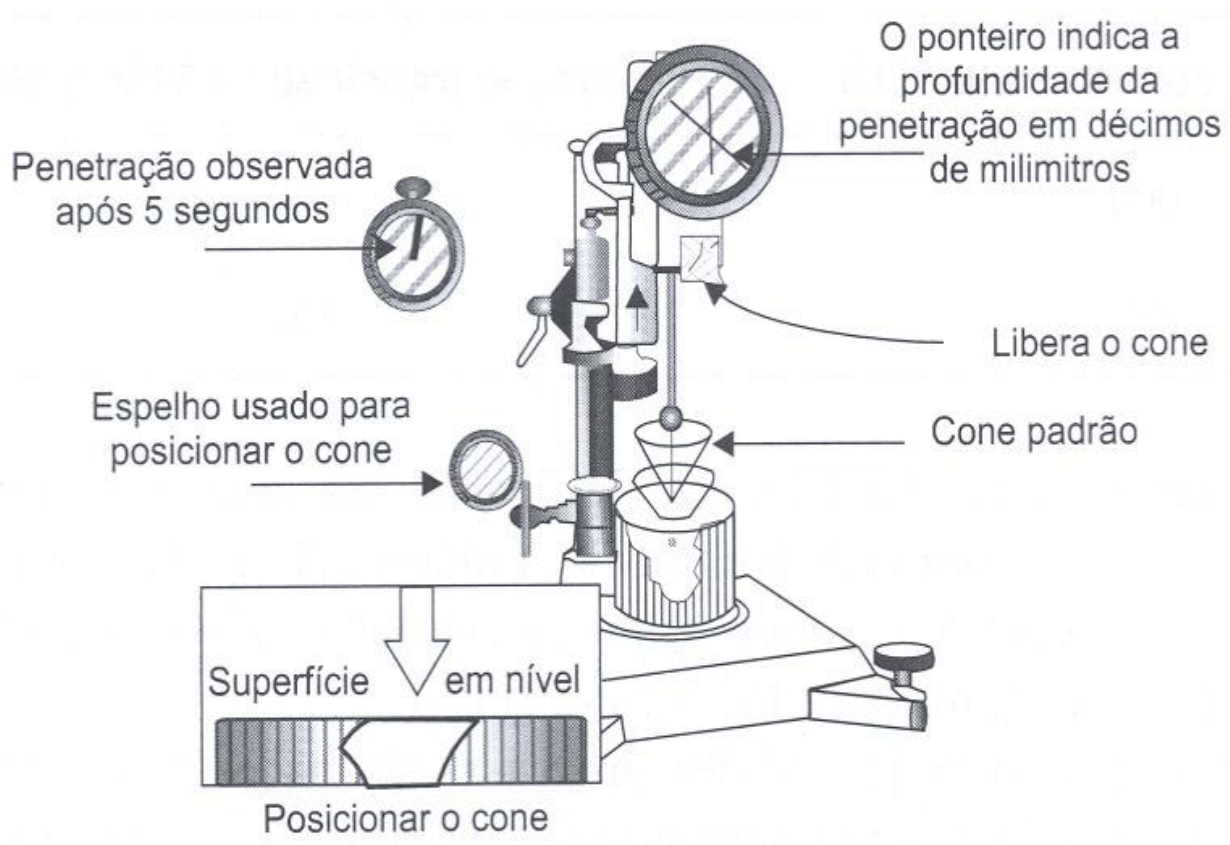

FIGURA 2. Penetrômetro (Fonte: Carreteiro, R.; Belmiro, P.; 2006, p. 99). 
O National Lubrication Grease Institute (NLGI) elaborou uma classificação universalmente adotada para graxas quanto à sua consistência conforme a tabela 1 . TABELA 1. Classificação da consistência de graxas de acordo com a penetração trabalhada.

Consistência NLGI

\begin{tabular}{ll}
\hline 000 & $445-475$ \\
00 & $400-430$ \\
0 & $355-385$ \\
1 & $310-340$ \\
2 & $265-295$ \\
3 & $220-250$ \\
4 & $175-205$ \\
5 & $130-160$ \\
6 & $85-115$ \\
\hline
\end{tabular}

(Fonte: Carreteiro; Belmiro, 2006).

Observa-se na tabela 1 que não existem alguns valores, por exemplo, 300 $\mathrm{mm} / 10$ que corresponde a uma graxa que está entre o número de consistência NLGI 1 e 2 da tabela, também existem casos de graxas muito duras que não podem ser classificadas (CARRETEIRO; BELMIRO, 2006).

\subsection{Graxas lubrificantes - Composição}

As graxas são caracterizadas em função dos três elementos básicos para a composição deste produto: O fluido lubrificante, o espessante e os aditivos, tendo em vista que o método de produção é fundamental, pois a fabricação de graxas é mais uma arte que propriamente uma técnica (CARRETEIRO; BELMIRO, 2006).

\subsubsection{Fluido lubrificante}

Pode ser utilizada uma grande variedade de fluidos lubrificantes em formulações de graxas, entre eles: óleos minerais, graxos ou sintéticos. A viscosidade e o tipo do óleo utilizado têm grande influência nas propriedades de uma 
graxa lubrificante quando se trata da espessura da película lubrificante, solvência do fluido e separação da fase líquida (CARRETEIRO; BELMIRO, 2006).

- Óleos minerais

São obtidos do petróleo e consequentemente as suas propriedades relacionam-se à natureza do óleo cru que the deu origem e ao processo de refinação empregado. Os mais utilizados são os de série parafínicas (alcanos) que possuem cadeias mais lineares e organizadas entre si, naftênicas (cicloparafinas) que são mais mistas e possuem um teor um pouco mais elevado de aromáticos quando comparados aos óleos parafínicos e os óleos de série aromática que sua composição se dá, em maior parte, por cadeias aromáticas.

\section{- Óleos graxos}

São óleos vegetais e animais compostos por cadeias mono ou poliinsaturadas, com alto grau de ácidos graxos que proporcionam altíssima lubricidade e aderência em superfícies metálicas, devido à sua alta polaridade. Atualmente tais óleos foram, em grande parte, substituídos por óleos minerais pelo motivo de poderem reagir em algumas aplicações específicas, alguns ainda são utilizados como, por exemplo, o óleo de mamona e canola, mas para processos em que não se tem altas temperaturas ou pressões.

- Óleos sintéticos

São óleos obtidos através de síntese orgânica com propriedades lubrificantes variadas. Entre os mais utilizados estão: ésteres de ácidos dibásicos, ésteres de organofosfatos, ésteres de silicatos, silicones, poliolefinas, poliglicóis e polifeniléteres. Os óleos sintéticos geralmente têm propriedades funcionais melhores que os óleos minerais e graxos, por terem suas cadeias mais estáveis e não se degradarem facilmente quando expostos a temperatura e pressão, mas em contra partida seu valor comercial é muito superior. 


\subsubsection{Espessantes}

Podem ser definidos como agentes modificadores da estrutura do fluido lubrificante, fazendo com que este obtenha uma maior viscosidade. A concentração de agente espessante, quando se trata de graxas à base de sabão metálico, sendo de $5 \%$ em peso resulta em uma graxa de grau NLGI número zero, o que corresponde a uma penetração trabalhada a $25^{\circ} \mathrm{C}$ de 355 a 385 [mm/10]. E para a concentração de $40 \%$ em peso, de espessante, resulta em uma graxa de grau NLGI número sete, correspondente a uma penetração trabalhada a $25^{\circ} \mathrm{C}$ de 40 a $70[\mathrm{~mm} / 10]$.

Esta relação, da porcentagem de agente espessante e consistência, varia de acordo com o tipo do espessante utilizado, porém a consistência de uma graxa será sempre uma função crescente da concentração da fase dispersa. A natureza química e concentração do espessante conferem as graxas determinadas características como: consistência, temperatura de trabalho, estrutura, comportamento na presença de água e às temperaturas elevadas (LUBARSA, 1970). Os espessantes são subdivididos em dois grupos básicos: sabão e não sabão.

\subsubsection{Espessantes à base de sabão metálico}

São sabões obtidos pela neutralização de um ácido graxo orgânico como, por exemplo, o ácido oléico e o ácido esteárico, por um produto alcalino como hidróxido de lítio, cálcio, sódio, alumínio ou bário em uma reação conhecida como saponificação. Um exemplo da reação de saponificação entre o ácido esteárico e o hidróxido de sódio, formando estearato de sódio (sabão) e água é demonstrado pela reação abaixo.

$$
\mathrm{C}_{17} \mathrm{H}_{35} \mathrm{COOH}+\mathrm{NaOH} \rightarrow \mathrm{C}_{17} \mathrm{H}_{35} \mathrm{COONa}+\mathrm{H}_{2} \mathrm{O}
$$

\subsubsection{Espessantes não sabão}

São compostos inorgânicos ou orgânicos insolúveis dentro do fluido lubrificante em todas as temperaturas, porém, são capazes de ligar-se ao óleo devido a sua estrutura superficial porosa. Os espessantes não sabão mais utilizados são as poliuréias (PUR), argilas oleaginosas (bentonitas), gel de sílica e plásticos como o politetrafluoretileno (PTFE) e o polietileno (PE) (RUNGE, 1994). 
Os espessantes à base de poliuréia destacam-se por apresentar alto ponto de gota (maiores que $250^{\circ} \mathrm{C}$ ), boa estabilidade térmica, alta durabilidade, boa resistência à água e boa proteção contra a corrosão. Estruturas de graxa de poliuréia são geralmente de três tipos: fibrosas, espiral e macarrão.

\subsubsection{Aditivos}

Os aditivos são compostos que conferem aos lubrificantes propriedades especiais ausentes ou presentes em grau insuficiente no óleo puro. Mesmo quando adicionados em pequenas quantidades, esses agentes podem modificar profundamente as propriedades de um óleo básico ou graxa lubrificante (HISSA, 1991). Os aditivos mais utilizados são os lubrificantes, antioxidantes, extrema pressão, tensoativos, inibidores de corrosão e promotores de adesividade.

A mistura do óleo com o espessante geralmente proporciona uma lubrificação satisfatória, porém, pode ocorrer a necessidade de adição de um agente para melhorar as propriedades lubrificantes da graxa. Esses agentes são principalmente gorduras, óleos ou sólidos (pó).

A utilização de lubrificantes sólidos é recomendada em condições extremas de alta carga com baixas velocidades, formando uma película sobre as superfícies metálicas evitando contato direto entre os metais (CARRETEIRO; BELMIRO, 2006). Os lubrificantes sólidos mais utilizados são grafite, bissulfeto de molibidênio e politetrafluoretileno, mais conhecido com o nome comercial Teflon ${ }^{\circledR}$, marca registra da empresa Dupont.

\subsection{Polímeros}

Polímeros são macromoléculas naturais ou sintéticas de elevada massa molar que resultam da repetição de monômeros. O reconhecimento da natureza química dos polímeros ocorreu em 1920, com estudos sobre borracha natural, amido e celulose.

Os polímeros são substâncias que apresentam ligações em cadeia entre átomos de carbono com outros elementos químicos. Estas ligações são predominantemente covalentes. A tabela 2 ilustra os tipos de ligações existentes 
(tripla, dupla ou simples), as energias associadas a estas e a distância entre os núcleos dos átomos ligados (comprimento da ligação). Tais ligações são fundamentais para a estabilidade do polímero, já que quanto maior sua estabilidade, maior será a energia de ligação necessária para quebrá-la (FERRAZ, 2013).

TABELA 2. Características de algumas ligações covalentes.

\begin{tabular}{cccc}
\hline EJ/mol & kcal/mol & Tipo & $\begin{array}{c}\text { Comprimento } \\
(\mathbf{A})\end{array}$ \\
\hline 890 & 212 & $\mathrm{C} \equiv \mathrm{C}$ & 0,12 \\
680 & 162 & $\mathrm{C}=\mathrm{C}$ & 0,13 \\
535 & 127 & $\mathrm{C}=\mathrm{O}$ & 0,12 \\
500 & 119 & $\mathrm{O}-\mathrm{H}$ & 0,10 \\
450 & 107 & $\mathrm{C}-\mathrm{F}$ & 0,14 \\
435 & 104 & $\mathrm{C}-\mathrm{H}$ & 0,11 \\
435 & 104 & $\mathrm{H}-\mathrm{H}$ & 0,074 \\
430 & 102 & $\mathrm{~N}-\mathrm{H}$ & 0,10 \\
375 & 89 & $\mathrm{O}-\mathrm{Si}$ & 0,16 \\
370 & 88 & $\mathrm{C}-\mathrm{C}$ & 0,154 \\
360 & 86 & $\mathrm{C}-\mathrm{O}$ & 0,14 \\
340 & 81 & $\mathrm{C}-\mathrm{Cl}$ & 0,18 \\
305 & 73 & $\mathrm{C}-\mathrm{N}$ & 0,15 \\
250 & 60 & $\mathrm{~N}-\mathrm{O}$ & 0,12 \\
220 & 52 & $\mathrm{O}-\mathrm{O}$ & 0,15 \\
16 & 38 & $\mathrm{~F}-\mathrm{F}$ & 0,14 \\
\hline
\end{tabular}

(Fonte: Adaptado de SHACKELFORD, 1996).

As ligações estão listadas por ordem da mais energética para a menos energética, assim é possível observar que nos polímeros existem átomos mais fortemente ligados dos que outros, sendo que a ligação mais forte é justamente entre os átomos de carbono. Uma das implicações destas diferentes forças de ligação seria a degradação diferenciada que os polímeros podem sofrer sob certas condições, por exemplo, sob a exposição à radiação, outra implicação prática seria a possibilidade de se obter materiais poliméricos mais resistentes quando é possível 
orientar as ligações mais fortes nestes materiais na direção de aplicação dos esforços mecânicos.

As estruturas das cadeias poliméricas podem ser classificadas de quatro formas: Linear, ramificada, reticulada ou em rede, dependendo do tipo de ligação entre elas e da presença de ligantes, como demonstrado na figura 3.
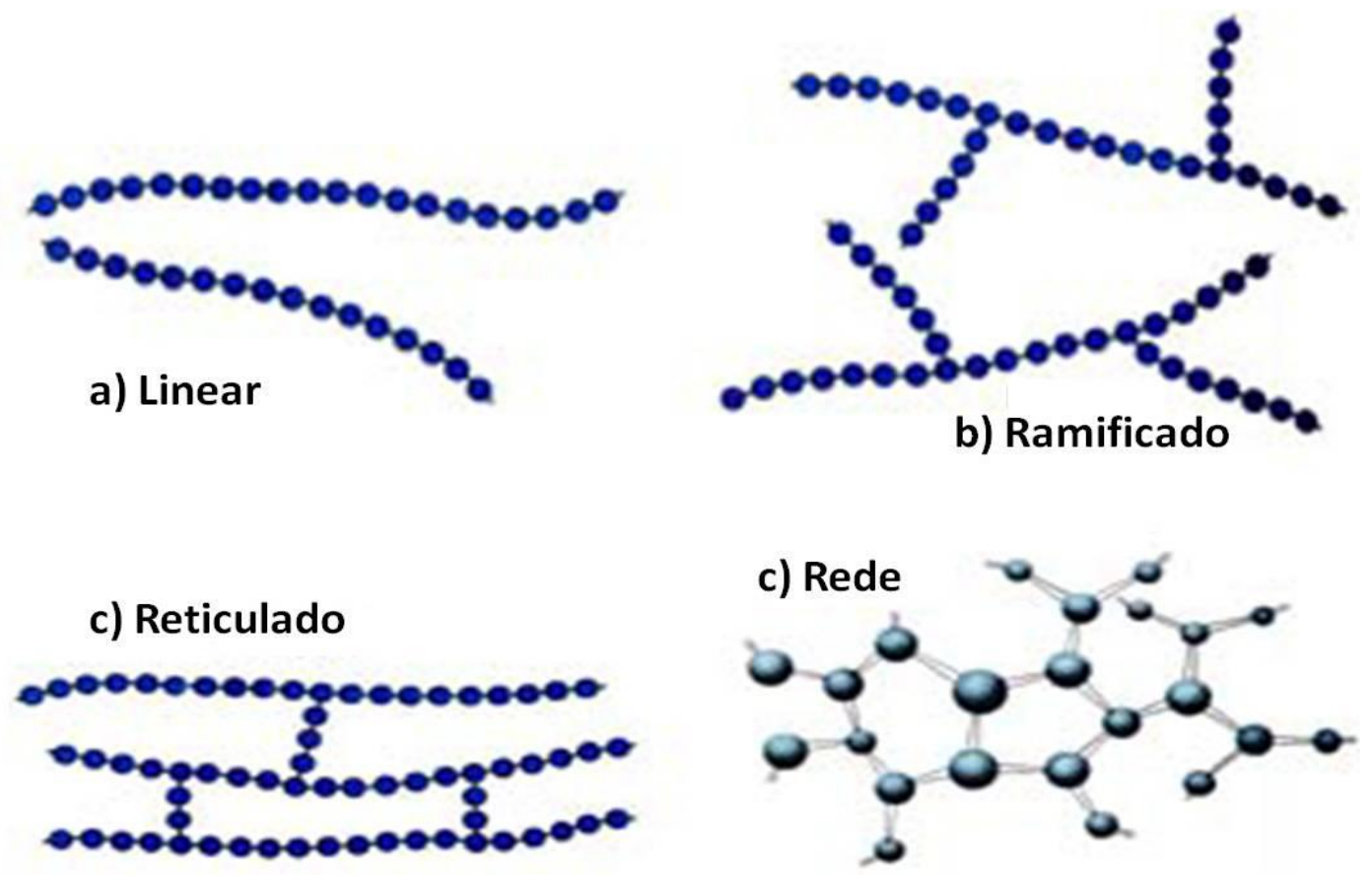

FIGURA 3. Representação esquemática da classificação de um polímero quanto à natureza de suas ligações e sua estrutura (Fonte: Adaptado de CALLISTER, 1997).

\subsubsection{Polialfaolefina (PAO)}

São oligômeros de olefinas hidrogenadas produzidas pela polimerização catalítica de alfaolefinas lineares. São constituídas de estruturas de isoparafinas livres de ceras que contém cadeias não ramificadas laterais de comprimento predeterminado. Como lubrificante é encontrada na forma líquida, incolor e translúcida em viscosidades bem variadas, a partir de 5 cSt até maior que 1000 cSt a $40^{\circ} \mathrm{C}$.

As polialfaolefinas exibem numerosas vantagens de desempenho em comparação com óleos minerais, vegetais e poliisobutenos. Essas vantagens incluem melhores propriedades em baixas temperaturas (ponto de fluidez e 
viscosidade), baixa volatilidade e estabilidade térmica melhorada, as PAO's possuem altíssima resistência á oxidação.

Possuem também elevados índices de viscosidade que se traduzem em melhor fluidez em baixas temperaturas e maior espessura de película lubrificante em altas temperaturas. Além disso, são estáveis ao cisalhamento e à hidrólise, tem boa compatibilidade com óleos minerais, e são freqüentemente misturadas a outras bases sintéticas (por ex: ésteres ou alquilnaftalenos) para aumentar sua capacidade de solvência e para o controle de depósitos (EXXONMOBIL, 2003).

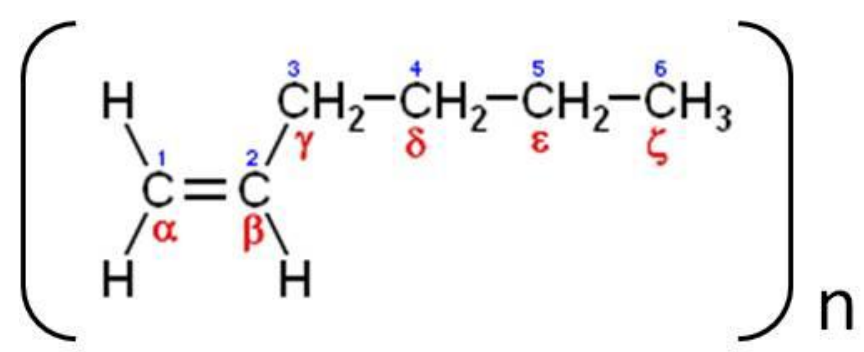

FIGURA 4. Representação química da estrutura da molécula de polialfaolefina (Fonte: Adaptada de http://en.wikipedia.org/wiki/Alpha-olefin).

\subsubsection{Poliuréia (PUR)}

A poliuréia é um produto resultante basicamente da reação entre isocianato e amina, é extremamente versátil, podendo ser aplicada em revestimentos anticorrosivos, selantes, impermeabilizantes e em graxas lubrificantes como espessante. Existem vários tipos de graxas à base de poliuréia [-RNCONR'-], que variam de acordo com o tipo de amina $\left[R-\mathrm{NH}_{2}\right]$, diaminas $\left[\mathrm{H}_{2} \mathrm{~N}-\mathrm{R}^{\prime}-\mathrm{NH}_{2}\right]$, isocianatos [R"-NCO], diisocianatos [OCN-R"'-NCO] e outros reagentes que podem ser utilizados na fabricação de graxas à base de poliuréia.

Apenas um tipo de poliuréia está presente na lista do USDA (United States Department of Agriculture - Departamento de agricultura dos Estados Unidos) de produtos aprovados como grau $\mathrm{H} 1$, que significa que o lubrificante pode ter contato incidental com alimentos, tais lubrificantes são muitas vezes considerados como "especiais", descrevendo a poliuréia como tendo um conteúdo de nitrogênio entre 9 a $14 \%$ baseado no peso da poliuréia seca, produzida pela reação do TDI (tolueno diisocianato) com uma amina derivada do ácido graxo de Tall Oil (óleo de madeira de 
Pinus, contendo de 16 a 18 carbonos por molécula) e etileno diamina, na razão molar de 2:2:1, para uso somente como adjuvante no óleo mineral lubrificante onde o nível não pode exceder 10\% em peso do óleo mineral (SEYMOUR, 1990).

Existem cinco reações principais dos isocianatos sendo elas polióis formando poliuretanos (PU), aminas resultando em poliuréias, água originando poliuréia e liberando gás carbônico que é o principal agente de expansão em espumas poliuretânicas, grupos uretano e uréia resultando na formação de ligações cruzadas alofonato e biureto (VILAR, 1998).

Álcool: $\mathrm{R}-\mathrm{NCO}+\mathrm{R}^{\prime}-\mathrm{OH} \longrightarrow \mathrm{RNH}-\prod_{\text {C-OR' (uretano) }}^{\mathrm{O}}$

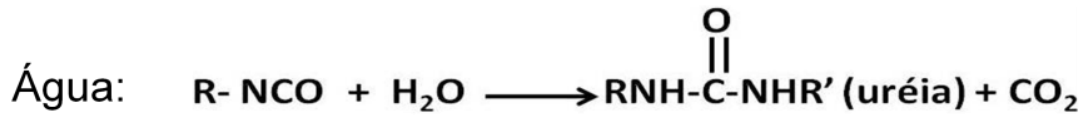

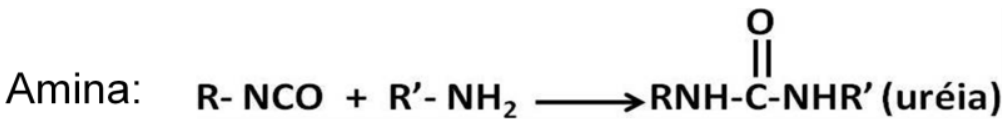

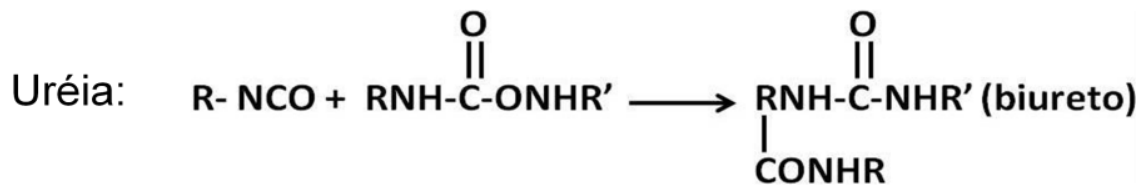

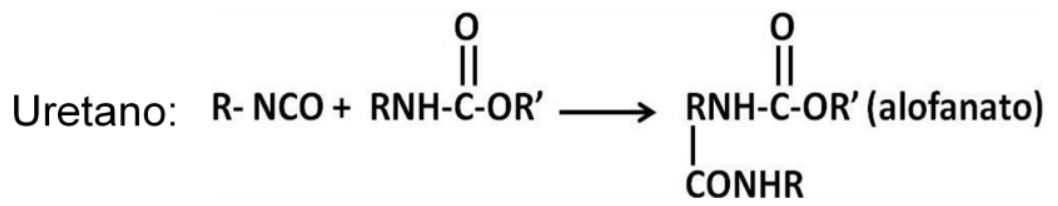

FIGURA 5. Representação das possíveis reações químicas dos isocianatos.

As reações dos isocianatos com aminas, formando poliuréias, são muito rápidas e não necessitam de catálise. Aminas alifáticas reagem mais rapidamente do que as aminas aromáticas de menor basicidade, desde que não haja impedimento estérico muito significativo. Em aminas aromáticas quanto maior a eletronegatividade dos substituintes do anel aromático, menor será a sua reatividade.

Em adição aos efeitos eletrônicos que influenciam a basicidade do nitrogênio amínico, o efeito estérico é um fator importante. Os substituintes na posição orto, da mesma forma que no caso dos isocianatos, retardam fortemente a 
velocidade de reação. As aminas alifáticas com alta reatividade têm a função de estender a cadeia (VILAR, 2004).

TABELA 3. Velocidade relativa de reações típicas dos isocianatos não catalisada a $25^{\circ} \mathrm{C}$.

\begin{tabular}{ccc}
\hline Composto com hidrogênio ativo & Estrutura típica & Velocidade relativa $^{*}$ \\
\hline Amina alifática primária & $\mathrm{R}-\mathrm{NH}_{2}$ & 100.000 \\
Amina alifática secundária & $\mathrm{RR}^{\prime}-\mathrm{NH}$ & $20.000-50.000$ \\
Amina aromática primária & $\mathrm{Ar}-\mathrm{NH}_{2}$ & $200-300$ \\
Hidroxila primária & $\mathrm{RCH}-\mathrm{OH}$ & 100 \\
Água & $\mathrm{HOH}$ & 100 \\
Ácido carboxílico & $\mathrm{RCOOH}$ & 40 \\
Hidroxila secundária & $\mathrm{RR} \cdot \mathrm{CH}-\mathrm{OH}$ & 30 \\
Uréia & $\mathrm{R}-\mathrm{NH}-\mathrm{CO}-\mathrm{NH}-\mathrm{R}$ & 15 \\
Hidroxila terciária & $\mathrm{RR} \mathrm{R}^{\prime \prime} \mathrm{C}-\mathrm{OH}$ & 0,5 \\
Uretano & $\mathrm{R}-\mathrm{NH}-\mathrm{CO}-\mathrm{O}-\mathrm{R}$ & 0,3 \\
Amida & $\mathrm{RCO}-\mathrm{NH} \mathrm{H}_{2}$ & 0,1
\end{tabular}

(Fonte: VILAR, 1998).

As diaminas são usadas na extensão da cadeia de pré-polímeros e obtenção de poliuretanos e poliuréias. O uso de diaminas alifáticas muito reativas e aromáticas secundárias menos reativas permite variar o perfil de reatividade dos sistemas.

A estrutura dos isocianatos tem importância na reatividade do grupo NCO. A reatividade dos isocianatos é aumentada por substituintes que elevem a carga positiva no carbono do grupo NCO. Assim, isocianatos alifáticos são menos reativos que os aromáticos. Estes serão mais reativos quanto maior a eletronegatividade dos substituintes do anel aromático. Em adição, o efeito eletrônico e os fatores estéricos também são importantes. Substituintes volumosos próximos ao centro de reação diminuem a velocidade de reação (VILAR, 1998). 
TABELA 4. Isocianatos comerciais.

\begin{tabular}{|c|c|c|c|}
\hline Nome comercial /científico & Estrutura & $\begin{array}{c}\text { Peso } \\
\text { Molecular }\end{array}$ & $\begin{array}{l}\text { Densidade } \\
\mathrm{g} / \mathrm{mL} \text { a } 20^{\circ} \mathrm{C}\end{array}$ \\
\hline $\begin{array}{c}2,4 \text { - Tolueno diisocianato } \\
\text { (TDI) / 2,4 - diisocianato de } 1 \text { - } \\
\text { metil - benzeno }\end{array}$ & & 174,2 & 1,061 \\
\hline $\begin{array}{c}2,6 \text { - Tolueno diisocianato } \\
\text { (TDI) / 2,6 - diisocianato de } 1 \text { - } \\
\text { metil - benzeno }\end{array}$ & & 174,2 & 1,2271 \\
\hline $\begin{array}{l}\text { Tolueno diisocianato } \\
\text { Mistura 2,4:2,6 = 65:35 } \\
\text { (TDI - 65 / 35) }\end{array}$ & --- & 174,2 & 1,222 \\
\hline $\begin{array}{l}\text { Tolueno diisocianato mistura } \\
2,4: 2,6=80: 20(\mathrm{TDI}-80 / 20)\end{array}$ & ----- & 174,2 & 1,221 \\
\hline
\end{tabular}

(Fonte: Adaptado de VILAR, 1998).

O tolueno diisocianato é normalmente comercializado como uma mistura dos isômeros 2,4 e 2,6 nas proporções 80/20 (TDI - 80/20), 65/35 (TDI - 65/35), ou puro (TDI-100). O TDI é o isocianato que apresenta maior reatividade no grupamento NCO localizado na posição 4 do anel aromático em relação aos grupos NCO nas posições 2 e 6.

No 2,4 - TDI, o grupo 4-NCO possui reatividade em média quatro vezes maior do que a do $2-\mathrm{NCO}$ e é $50 \%$ mais reativo do que o $4-\mathrm{NCO}$ do difenilmetano diisocianato (MDI). Nos diisocianatos que contêm dois grupos NCO no mesmo anel aromático, a reatividade é dependente do efeito ativador do outro grupo substituinte. $O$ decréscimo da reatividade é maior se outro substituinte estiver presente em posição orto em relação ao segundo NCO. 
Logo que o primeiro NCO reage, por exemplo, com um álcool, o grupo NCO remanescente passa a ter a reatividade de um monoisocianato com um substituinte uretano, e o grupo uretano tem efeito ativador menor do que o grupo NCO na mesma posição. No TDI o grupo NCO, na posição para, reage mais rapidamente do que o $\mathrm{NCO}$ em posição orto. $\mathrm{Na}$ temperatura ambiente, se considerarmos como $100 \%$ a reatividade do grupo NCO na posição para do 2,4 TDI, a do grupo NCO em orto seria $12 \%$.

No 2,6 - TDI a reatividade do primeiro grupo NCO seria $56 \%$ e a do segundo cairia para $17 \%$. Todavia, quando a temperatura se aproxima dos $100^{\circ} \mathrm{C}$, os efeitos estéricos são minimizados e ambas as posições tem reatividades próximas (VILAR, 1998).

\subsubsection{Politetrafluoretileno (PTFE)}

É um fluoropolímero, ou seja, sua cadeia polimérica é composta por átomos de carbonos e flúor, que substituíram os átomos de hidrogênio, o que agrega a este polímero características especiais, como: inércia, antiaderência, baixíssimo coeficiente de atrito, baixa toxidade, impermeabilidade, aceitação do corpo humano (D. DOWSON; 2003).

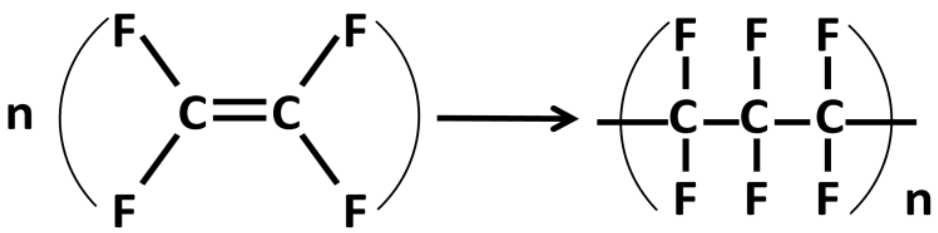

Monômero

Polímero

FIGURA 6. Representação da polimerização do politetrafluoroetileno.

É conhecido mundialmente pelo nome comercial Teflon®, marca da empresa multinacional DuPont. Foi descoberto acidentalmente durante um experimento de Roy J. Plunkett, em 1938, e apresentado para fins comerciais em 1946.

Além de suas utilidades mais conhecidas, como fabricação de utensílios plásticos, revestimentos de panelas antiaderentes e próteses, o PTFE em pó é amplamente utilizado como lubrificante em óleos, graxas ou até mesmo puro. Em 
graxas pode ser utilizado como o próprio espessante do fluido lubrificante ou como aditivo lubrificante por ser o material com o menor coeficiente de atrito já conhecido.

\subsubsection{Compatibilidade entre polímeros}

O principal fator sobre a compatibilização entre materiais é a afinidade química entre eles, alguns exemplos são: polaridade, eletronegatividade, função orgânica, tamanho da cadeia, raio atômico, ramificações, tipos de ligantes, entre outros. No caso dos polímeros especificamente, o seu peso molecular, sua estrutura e suas ramificações são fatores cruciais para determinar sua compatibilidade com outro polímero.

Os polímeros por terem cadeias longas e alto grau de saturação são mais inertes, ou seja, quimicamente mais estáveis e praticamente não interagem com outras substâncias, quando comparados a outras substâncias químicas de cadeias menores. O que pode vir a interagir em suas cadeias são os halogênios e oxigênios presentes, por isso para melhorar sua compatibilidade com outros materiais pode ser necessário realizar mudanças em sua cadeia, mas por serem extremamente resistentes a reações, é comum o uso de radiação para conseguir tal modificação (SHACKELFORD; 1996).

No PTFE o uso de radiação ionizante ou ultravioleta é comum para reduzir o tamanho de sua cadeia, formar grupos terminais oxigenados e diminuir o tamanho de sua partícula final, tornando-o adequado para lubrificação. No mercado de lubrificantes é possível encontrar pelo menos dois tipos de PTFE irradiados em ar, um irradiado por ultravioleta, fabricado pela Dupont e outro oriundo do reaproveitamento de aparatos de PTFE (resíduos de usinagens), ou seja, um PTFE reciclado com certo grau de degradação e processado por radiação ionizante.

A radiação pode provocar diferenças de desempenho em polímeros absolutamente distintas, principalmente quando se trata de lubrificação, pois o aumento de polaridade e tamanho de partícula são cruciais para determinar o poder lubrificante de um material. 


\subsubsection{Efeitos da radiação}

O processo de irradiação é um método muito conhecido e utilizado para a modificação de polímeros. Quando esta radiação interage com a matriz polimérica, sua energia é absorvida e ativam espécies, são produzidos radicais que iniciam várias reações químicas nas vizinhanças, as cadeias moleculares podem propagarse através das espécies de radicais que são geradas dentro e fora da cadeia, por radiação (COLOMBO, 2004).

Os principais efeitos da radiação em polímeros são:

1) reticulação: ocorre quando as cadeias poliméricas se interligam e formam uma rede de ligações cruzadas;

2) decomposição: a consequência é a diminuição da massa molar do polímero devido à cisão (quebra) de cadeias;

3) enxertia: ocorre quando um novo monômero é polimerizado e se liga na cadeia polimérica. Quando os monômeros são irradiados, a sua homopolimerização também pode ser iniciada.

\subsubsection{Radiação lonizante}

A escolha de uma fonte de radiação depende da natureza, do tipo e da estrutura do material a ser irradiado. Materiais como polímeros que na maioria das vezes se apresentam em estado sólido, geralmente necessitam de uma radiação mais penetrante, como a radiação gama. As radiações menos penetrantes, porém, como $\alpha, \beta$ ou elétrons de baixa energia, podem ser usadas com a finalidade de irradiar uma camada superficial da amostra (KRANE, 1987).

As fontes de radiação ionizante mais utilizadas correspondem a fonte de ${ }^{60} \mathrm{Co}$, que utiliza radiação gama e os aceleradores de elétrons, que por sua vez, utilizam feixes de elétrons (SPINKS \& WOODS, 1990).

A radiação gama é uma onda eletromagnética de alta energia (fótons de alta energia) de origem nuclear, sem carga e sem massa. Seus comprimentos de onda encontram-se na região entre $3.10^{-9} \mathrm{~cm}$ a $3 \cdot 10^{-11} \mathrm{~cm}$.

Os raios gama são emitidos dos núcleos radioativos com energias bem definidas, correspondentes à diferença entre os níveis de energia de transição do 
núcleo. A transição pode ocorrer entre dois níveis excitados ou entre um nível excitado e o nível fundamental (estado de mínima energia). Deste modo, pode haver a emissão de um ou mais raios-gamas em cada desintegração. A energia dos raiosgama emitidos pelos diferentes nuclídeos está na faixa de aproximadamente 0,03 a 3 $\mathrm{MeV}$. O ${ }^{60} \mathrm{Co}$, por exemplo, fornece fótons de energia igual a 1,173 e 1,332 MeV (SPINKS \& WOODS, 1990).

Os raios gama, diferentemente das partículas alfa e beta (elétrons), tendem a perder a maior parte de energia dos seus fótons por meio de interações únicas. Isto significa que, enquanto as partículas alfa e os elétrons são barrados por absorvedores finos, uma fração dos fótons gama, em uma mesma situação, são completamente absorvidos, mas o restante é transmitido com sua energia inicial total (SPINKS \& WOODS, 1990).

\subsubsection{Radiação ultravioleta}

A radiação ultravioleta cobre a região do espectro eletromagnético entre 400 e 100 nm. O Comitê Internacional da lluminação (Commission Internacional de I'Eclairage) recomenda a classificação em UV-A (400-315 nm), UV-B (315-280 nm) e UV-C (280-100 nm), sendo que, se refere à primeira faixa como ultravioleta próximo e à última, como ultravioleta extremo ou de vácuo. A denominação de ultravioleta de vácuo deve-se à necessidade de, ao se operar em baixos comprimentos de onda, remover $\mathrm{O}_{2}$ atmosférico que absorve radiação em $\lambda<200 \mathrm{~nm}$. (WAYNE, R. P., 1988).

Na prática, o aproveitamento do espectro ultravioleta é limitado pelos três tipos de fontes disponíveis comercialmente: lâmpadas de deutério, xenônio e vapor de mercúrio. Entre elas, as de vapor de mercúrio são as mais usadas em aplicações de laboratório e industriais, quando não é exigida muita estabilidade (no que as lâmpadas de deutério são mais favoráveis) ou amplo leque de emissão. O uso da radiação ultravioleta para a decomposição de matrizes orgânicas surgiu entre a década de 1960 e 1970, por Golimowski.

Considerando especificamente os polímeros, estes podem ser divididos em dois tipos de sistemas que absorvem luz: intrínsecos e extrínsecos. Os 
intrínsecos são quando o polímero possui em sua estrutura grupamentos químicos que sofrem transições eletrônicas ao absorver luz nas faixas de comprimento de onda abrangidas pelo espectro solar ou pelo espectro das lâmpadas usadas em iluminação artificial. Os extrínsecos são contaminações ou defeitos na cadeia que absorvem luz na região do espectro solar.

Os grupos químicos mais comuns, presentes nos polímeros ou nas suas contaminações, que serão responsáveis pela absorção de luz na região do espectro solar são: as ligações duplas $\mathrm{C}=\mathrm{C}$ conjugadas, os anéis aromáticos (C6H5) ou a ligação $C=O$. Estas ligações darão origem a transições, levando a formação de radicais livres (Cavicchioli, A.; Gutz, I., 2003). 


\section{MATERIAIS E MÉTODOS}

\subsection{Materiais}

Os materiais utilizados para a síntese da poliuréia (PUR) foram:

- Fluido polialfaolefina Spectrasyn $8^{\circledR} \mathrm{com}$ viscosidade $46 \mathrm{cSt}$ da empresa Exxon Mobil.

- Fluido polialfaolefina Spectrasyn $40^{\circledR}$ com viscosidade 460 cSt da empresa Exxon Mobil.

- Tolueno diisocianato $80 / 20$ com pureza de $99,5 \%$, peso molecular $174,2 \mathrm{~g} / \mathrm{mol}$ da empresa Dow Chemicals.

- Monoamina de cadeia de aproximadamente 12 carbonos, com pureza de $99,9 \%$.

- Diamina de cadeia menor que 5 carbonos, com pureza de 98,0\%.

- Agitador mecânico e vaso reator metálico fechado de 4 litros da marca Hipperquímica.

Os materiais utilizados para a aditivação da graxa de poliuréia foram:

- Politetrafluoretileno (PTFE) irradiado por ultravioleta Zonyl MP $1100^{\circledR}$ com densidade 2,20-2,30 $\mathrm{g} / \mathrm{cm}^{3}$, partículas de $4 \mu \mathrm{m}$ da empresa Du Pont.

- Politetrafluoretileno (PTFE) irradiado por radiação ionizante Unilub L $400^{\circledR}$ com densidade $2,10-2,20 \mathrm{~g} / \mathrm{cm}^{3}$, partículas de $4 \mu \mathrm{m}$ da empresa Uniflon.

\subsection{Métodos}

\subsubsection{Síntese da poliuréia (PUR)}

A poliuréia, no caso do presente trabalho, tetrauréia, foi obtida a partir da reação de uma monoamina alifática de cadeia longa, uma diamina alifática de cadeia curta e um diisocianato aromático (TDI), utilizando a polialfaolefina como veículo e 
fluido lubrificante, foi calculada a estequiometria da reação para se obter uma concentração de $20 \%$ de tetrauréia na graxa final resultando em um grau de consistência NLGI 2, conforme reação a seguir.

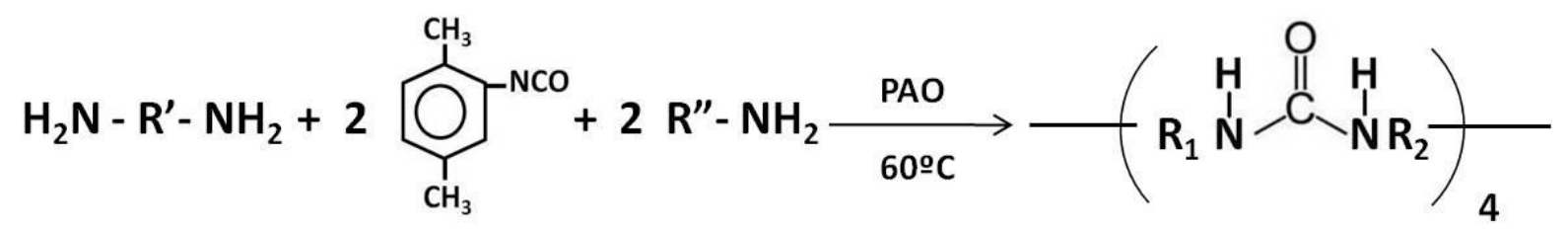

FIGURA 7. Reação de síntese da tetrauréia em polialfaolefina a $60^{\circ} \mathrm{C}$.

Um terço da polialfaolefina foi mantido sob aquecimento $\left(\sim 60^{\circ} \mathrm{C}\right)$ e agitação constante em baixa rotação ( 120rpm), os reagentes foram adicionados lentamente, separadamente e simultaneamente, diluídos no fluido de polialfaolefina, as aminas em um terço da PAO e o TDI em outro terço, conforme esquema a seguir.

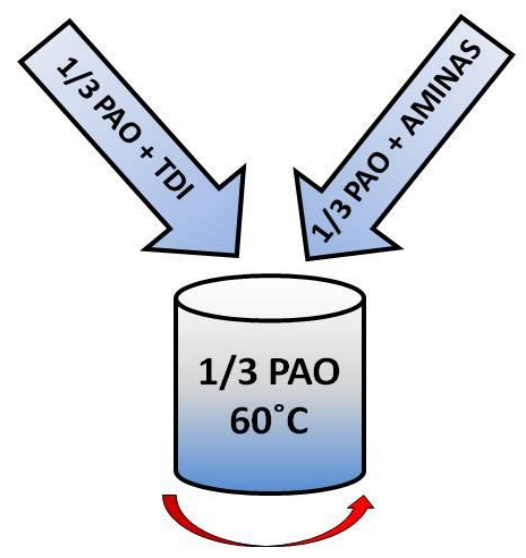

FIGURA 8. llustração do arranjo experimental para a síntese de poliuréia.

Para a reação ser completa foi mantido por 1 hora e 30 minutos, 0 aquecimento e a agitação da graxa por uma hélice tipo âncora, especialmente desenvolvida para evitar a quebra das fibras da graxa.

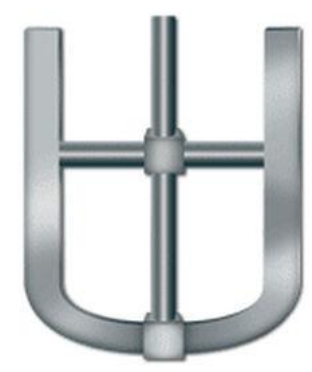

FIGURA 9. Ilustração da hélice do reator utilizada na síntese da poliuréia (Fonte: http://www.mmc-equipamentos.com.br/folderAgitadores.htm). 
Para finalizar, a graxa foi processada em um moinho de três rolos para perfeita homogeneização do espessante (PUR) no fluido (PAO).

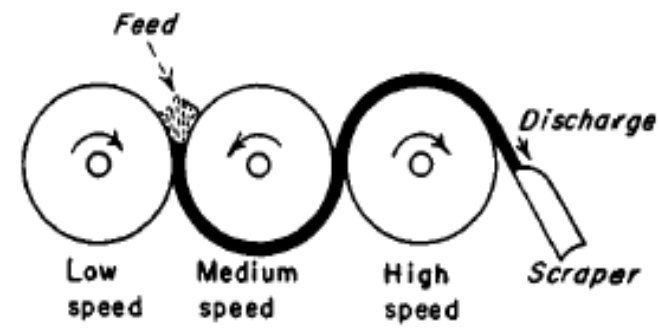

FIGURA 10. Ilustração do moinho de três rolos para processamento de graxas lubrificantes (Fonte: http://www.metalica.com.br/artigos-tecnicos/britadores-emoinhos).

\subsubsection{Adição de Politetrafluoretileno (PTFE) irradiado}

Foi adicionado sobre a graxa base (poliuréia em polialfaolefina) o PTFE em pó, que já é fornecido funcionalizado, ou seja, triturado e irradiado para se obter partículas menores adequadas para lubrificação.

A graxa foi separada em duas amostras, uma foi aditivada com PTFE irradiado por ultravioleta cedido pela empresa DuPont, de marca comercial Zonyl MP 1100 , com partículas de aproximadamente $4 \mu \mathrm{m}$ e a outra amostra foi aditivada com 0 PTFE processado por radiação ionizante cedido pela empresa Uniflon, de marca comercial Unilub $L 400$, com partículas do mesmo tamanho $(4 \mu \mathrm{m})$ para comparação da eficiência de ambos lubrificantes sólidos.

Após a adição do PTFE foi realizada a homogeneização por agitação em baixa rotação ( 120rpm) por uma hélice apropriada, tipo âncora, em seguida a graxa foi processada novamente no moinho de três rolos para perfeita dispersão do PTFE na graxa.

\subsection{3 Índice de NCO livre}

O estudo do índice de NCO livre na amostra de graxa de tetrauréia foi realizado no laboratório de pesquisas e desenvolvimentos da empresa Maxioil do Brasil ICPQ Ltda, foi seguida a norma ASTM D-5155-10. A amostra da graxa foi reagida com Dibutilamina, foi adicionado o indicador verde de bromocresol e em 
seguida a amostra foi titulada com solução de ácido clorídrico. O resultado é calculado em porcentagem de NCO livre na amostra.

\subsubsection{Espectroscopia de Absorção no Infravermelho por Transformada de Fourier (FTIR)}

Os espectros de absorção na região do infravermelho (4000 a $400 \mathrm{~cm}^{-1}$ ) foram obtidos em um espectrômetro Thermo Scientific Nicolet 6700 FT-IR, Smart Orbit, PIKE MIRacle com cristal de ZnSe por Refletância Total Atenuada (ATR) com detector MCT, resolução de $4 \mathrm{~cm}^{-1}, 96$ interferogramas por espectro. As análises foram obtidas à temperatura ambiente ( 298K). O equipamento utilizado pertence ao Centro de Célula a Combustível e Hidrogênio.

\subsubsection{Análise elementar}

O estudo da análise elementar da tetrauréia foi realizado na Central Analítica localizada no Instituto de Química dentro do campus da USP, foi utilizado o equipamento Perkin-Elmer CHN 2400, nesse estudo foram determinadas as quantidades, em porcentagem, de átomos de Carbono, Nitrogênio e hidrogênio, por exclusão também foi possível especular a quantidade de átomos de Oxigênio da molécula de tetrauréia obtida. Para separar a poliuréia do óleo foi realizada lavagem com hexano e também, como comparativo, foi realizada a obtenção de PUR diretamente em xileno.

\subsubsection{Microscopia eletrônica de varredura (MEV)}

Para obtenção das imagens por MEV foi utilizado um microscópio eletrônico de varredura marca Hitachi modelo TM 3000. As amostras foram pulverizadas sobre um suporte metálico adequado e recobertas com ouro pela técnica de spputering. O microscópio utilizado pertence ao Laboratório de microscopia eletrônica de varredura do Centro de Ciência e Tecnologia dos Materiais (CCTM) no Instituto de Pesquisas Energéticas e Nucleares (IPEN) na USP. Para separar a poliuréia do óleo foi realizada lavagem com hexano e também, como comparativo, foi realizada a obtenção de PUR diretamente em xileno. 


\subsubsection{Calorimetria exploratória diferencial (DSC)}

Para estudar as diferenças estruturais entre o PTFE irradiado por ultravioleta e por radiação ionizante, ambos os polímeros foram submetidos ao teste de calorimetria exploratória diferencial (DSC). As curvas de DSC foram obtidas com o equipamento DSC 822 da empresa Mettler-Toledo, sob atmosfera de nitrogênio entre 30 a $400^{\circ} \mathrm{C}$, a $10^{\circ} \mathrm{C} \cdot \mathrm{m}^{-1}$. O equipamento está alocado no Centro de Química e Meio Ambiente, no IPEN/CNEN-SP.

\subsubsection{Estudo da temperatura de gota da graxa}

O estudo da temperatura em que a graxa goteja foi realizado no equipamento de ponto de gota de acordo com a norma ABNT NBR 6564, indica a temperatura na qual a graxa passa do estado semi-sólido para o fluido e goteja, ou seja, a partir desta análise pode-se tirar a referência da temperatura máxima de trabalho da graxa. Para realizar este ensaio foi colocada uma pequena quantidade de graxa em uma cápsula metálica que possui um pequeno orifício no fundo, a cápsula é colocada dentro de um tubo de vidro e o esse tubo, por sua vez, introduzido em um banho que é aquecido lentamente até a temperatura em que a primeira gota da graxa dentro da cápsula escorre pelo orifício se acumulando no fundo do tubo de vidro, esta temperatura é chamada de ponto de gota.

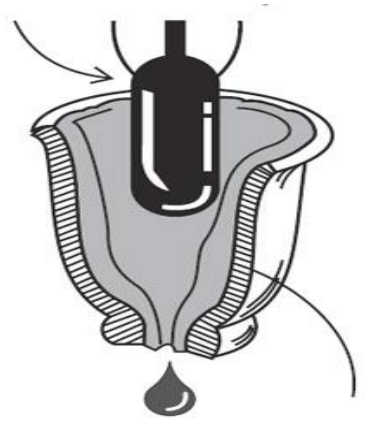

FIGURA 11. Ilustração da análise de ponto de gota de graxa lubrificante (Fonte: http://www.forlub.com.br/hotsite.php?id=81682\&option=\&id linha=7682\&id coluna=1 \&id noticia=1) 


\subsubsection{Estudo da separação de óleo}

O estudo da porcentagem de óleo que migra da graxa em repouso sob alta temperatura mostra a estabilidade e compatibilidade do espessante com o fluido lubrificante. Uma determinada quantidade de graxa é colocada em um cone posicionado dentro de um recipiente previamente pesado e o sistema é submetido a uma temperatura de $100^{\circ} \mathrm{C}$ pelo período de 30 horas, ao final do ensaio é avaliada a quantidade de óleo, em massa, que migrou para a superfície da graxa. O teste é feito seguindo a norma ASTM D6184 e nos dá uma referência do comportamento da graxa quando em estoque.

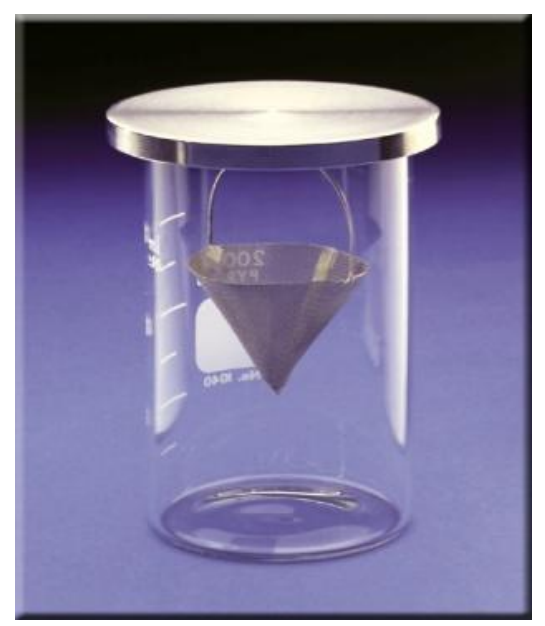

FIGURA 12. Instrumento para análise de separação de óleo da graxa (Fonte: http://www.koehlerinstrument.com/products/K19000.html).

\subsubsection{Estudo de penetração não trabalhada e trabalhada}

Nesse estudo foi medida a penetração por cone da graxa no equipamento penetrômetro e foi acompanhada sua variação quando em repouso e quando em trabalho (ABNT NBR 11345). São adicionados a um recipiente metálico padronizado aproximadamente $400 \mathrm{~g}$ de graxa, o recipiente é posicionado em baixo de um cone metálico padronizado que por meio de um botão é acionado e penetra na graxa. $\mathrm{O}$ equipamento possui um relógio que marca a penetração do cone na graxa, em décimos de milímetros, e por intermédio de uma tabela o valor da penetração é convertido em consistência. A variação de penetração mostra a estabilidade física da graxa, se ela endurece ou amolece, simulando o trabalho de uma máquina. 


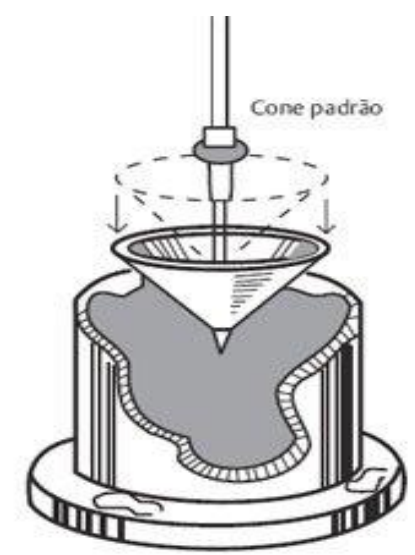

FIGURA 13. Análise de penetração da graxa (Fonte: http://www.forlub.com.br/hotsite.php?id=81682\&option=\&id linha=7682\&id coluna=1 \&id noticia=1).

\subsubsection{Estudo das características de extrema pressão e antidesgaste por quatro esferas}

- Solda

A característica de extrema pressão foi determinada pelo equipamento quatro esferas, mas conhecido como Four Ball, seguindo a norma ASTM D2596. Quatro esferas de aço padronizadas são lubrificadas com a graxa estudada e são posicionadas de acordo com a figura 14, a esfera superior fica em constante rotação e as esferas inferiores são submetidas à cargas padronizadas que vão aumentando em períodos determinados, assim as esferas inferiores são pressionadas sobre a esfera superior. A carga em que acontece a solda (solda) é determinada e o teste é refeito sendo interrompido uma carga anterior à solda (passa) e nesse momento é medida a escoriação (desgaste) causada na superfície da esfera superior. 
a)

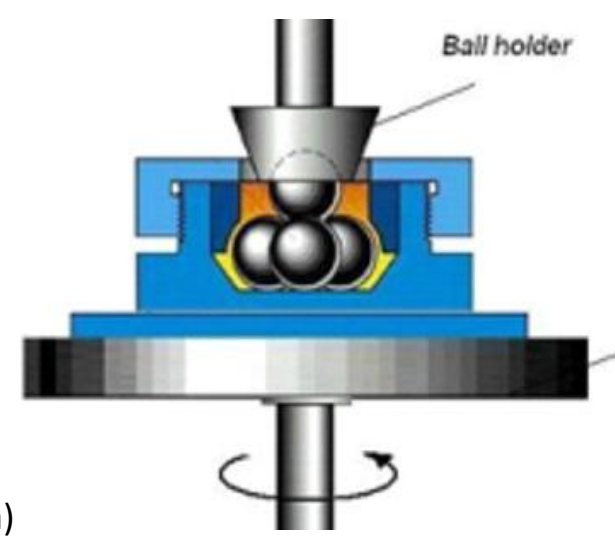

b)

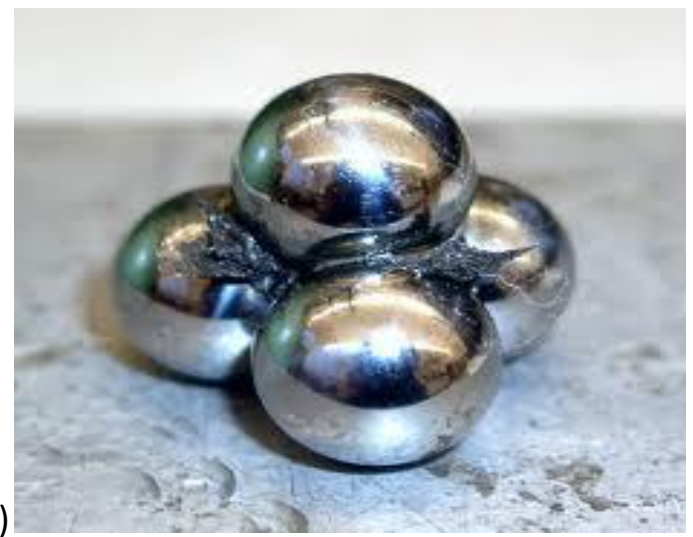

FIGURA 14. a) Ilustração do equipamento de quatro esferas "Four Ball" e b) esferas soldadas após

0 teste.

(Fonte:

http://www.timegroup.com.cn/templates/en/second.aspx?nodeid=116\&page=Content Page\&contentid=832).

\section{- Desgaste}

A característica de antidesgaste foi determinada pelo equipamento quatro esferas, seguindo a norma ASTM D2266, quatro esferas são lubrificadas com a graxa estudada, a esfera superior fica em constante rotação e as esferas inferiores são submetidas a uma carga padronizada sendo pressionadas sobre a esfera superior por $1 \mathrm{~h}$, ao final do ensaio é medida a escoriação na superfície da esfera superior e a partir dessa medida temos um parâmetro da resistência ao desgaste do lubrificante testado.

\subsubsection{Estudo do desempenho de graxas em rolamentos}

Este estudo é realizado em um mancal com quatro rolamentos fechados, a rotação é mantida em 2000 rpm e a temperatura em $200^{\circ} \mathrm{C}$, ambas condições podem ser alteradas dependendo do teste. Aproximadamente $5 \mathrm{~g}$ de cada graxa são aplicadas nos rolamentos, o equipamento é preparado e o teste é iniciado. A análise é tanto comparativa como qualitativa, observando os aspectos de aparência, cor, adesividade no ponto lubrificado, escorrimento, consistência visual, migração de óleo, aspecto dos rolamentos. Este teste não é normatizado, porém simula perfeitamente o trabalho prático da graxa lubrificante. 


\section{RESULTADOS E DISCUSSÕES}

\subsection{Características qualitativas}

\subsubsection{Síntese da tetrauréia em polialfaolefina}

Para realização da síntese da poliuréia foram testadas diversas monoaminas, diaminas e até poliaminas combinando-as e reagindo-as com um diisocianato aromático para obtenção da poliuréia em polialfaolefina, entre as aminas testadas estão: ciclohexilamina, diciclohexilamina, orto-toluidina, anilina, polioxipropilenodiamina, bis(2-aminopropril) éter, polioxialquilenoamina, trimetilolpropano polioxipropilenotriamina, dodecilamina, etilenodiamina (EDA) e hexametilenodiamina (HMD). Todas as reações foram exotérmicas e foram determinados outros aspectos importantes para graxas, conforme tabela 5 .

TABELA 5 - Resultados das reações entre diversos tipos de aminas e TDI.

\begin{tabular}{lcccccc}
\hline \multicolumn{1}{c}{$\begin{array}{c}\text { Aminas reagidas } \\
\text { com TDI }\end{array}$} & $\begin{array}{c}\text { Velocidade } \\
\text { da reação }\end{array}$ & $\begin{array}{c}\text { Aspecto } \\
\text { da } \\
\text { graxa }\end{array}$ & Arenoso & Cor & NLGI & $\begin{array}{c}\text { Ponto } \\
\text { de gota }\end{array}$ \\
\hline Diciclohexilamina & Rápida & Grumos & Sim & Branco & 0 & - \\
Ciclohexilamina & Rápida & Líquida & Pouco & Branco & $0 / 1$ & $260^{\circ} \mathrm{C}$ \\
O-Toluidina & Lenta & Pastoso & Pouco & Rosa & $0 / 1$ & $240^{\circ} \mathrm{C}$ \\
Dodecilamina & Média & Gel & Não & Branco & 0 & $140^{\circ} \mathrm{C}$ \\
Fenilamina & Média & Pastoso & Sim & Branco & 2 & $240^{\circ} \mathrm{C}$ \\
Etilenodiamina (EDA) & Rápida & Pastoso & Não & Branco & 2 & $250^{\circ} \mathrm{C}$ \\
Polioxipropilenodiamina & Rápida & Grumos & Não & Branco & - & - \\
Bis(2-aminopropril) éter & Rápida & Grumos & Não & Branco & - & - \\
Polioxialquilenoamina & Média & Grumos & Não & Branco & - & - \\
Trimetilolpropano & Lenta & Grumos & Não & Branco & - & - \\
polioxipropilenotriamina & Rápida & Pastoso & Não & Branco & 2 & $220^{\circ} \mathrm{C}$ \\
Hexametilenodiamina & Rápida & Pastoso & Não & Branco & 2 & $260^{\circ} \mathrm{C}$ \\
EDA + Dodecilamina & Rápida & Pastoso & Não & Branco & $0 / 1$ & $220^{\circ} \mathrm{C}$ \\
EDA + Diciclohexilamina & Média & Pastoso & Não & Branco & 0 & $200^{\circ} \mathrm{C}$ \\
EDA + Ciclohexilamina & Média & Pastoso & Sim & Rosa & $0 / 1$ & $250^{\circ} \mathrm{C}$ \\
EDA + O-Toluidina & & Pastoso & Não & Branco & 1 & $240^{\circ} \mathrm{C}$ \\
HMD + Dodecilamina & Rápida & Pastoso & Não & Branco & $0 / 1$ & $220^{\circ} \mathrm{C}$ \\
HMD + & Média & Pastoso & Não & Branco & 0 & $200^{\circ} \mathrm{C}$ \\
Diciclohexilamina & Média & Pastoso & Não & Branco & $0 / 1$ & $240^{\circ} \mathrm{C}$ \\
HMD + Ciclohexilamina & & & & & & \\
HMD + O-Toluidina & & &
\end{tabular}


Foi selecionada a mistura de dodecilamina e a etilenodiamina pelos seus excelentes resultados prévios. O produto resultante desta reação foi de aspecto branco, pastoso, com consistência similar a de um creme dental, mostrando que a tetrauréia foi bem dispersa na polialfaolefina e que houve o espessamento do fluido, que é a principal característica esperada do espessante.

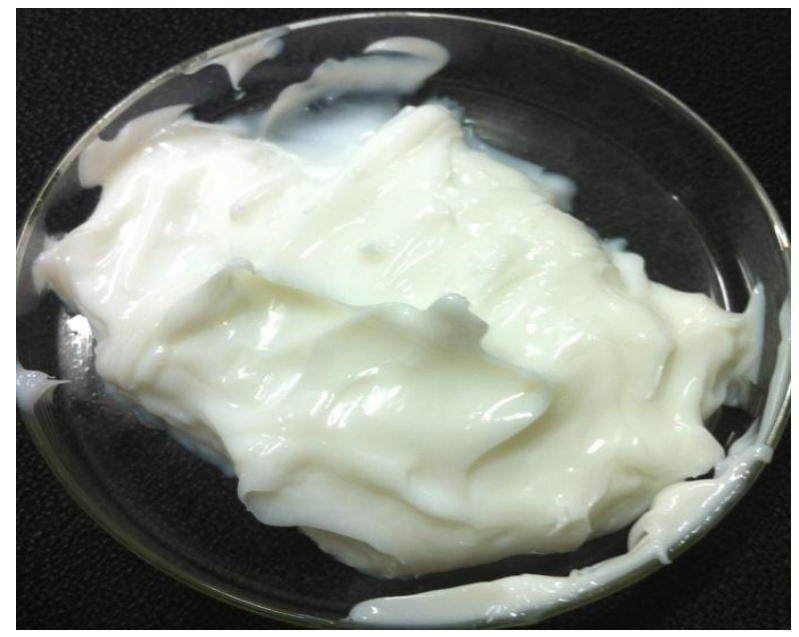

FIGURA 15. Fotografia da graxa de poliuréia após a reação.

\subsection{2 Índice de NCO livre}

Foi realizada a análise de índice de NCO livre na amostra, determinando a porcentagem de grupos NCO disponíveis para reagir na graxa de tetrauréia. esperado é que esse índice seja o mais baixo possível já que o isocianato é um produto tóxico, porém quando reagido se torna inofensivo nas condições normais de temperatura e pressão. Foi testada a graxa de tetrauréia e o isocianato puro como comparativo (RASP; TIMMERMANN; PERREY; LEHMANN; KUSSI, 1992).

TABELA 6 - Resultados da análise de NCO livre na amostra da graxa.

\begin{tabular}{cc}
\hline Amostra & \% de NCO \\
\hline TDI puro & 49,39 \\
Graxa de tetrauréia & 1,64
\end{tabular}

$\mathrm{Na}$ amostra de isocianato puro foi determinada a presença de $49,39 \%$ de grupos NCO disponíveis para reagir, representando $100 \%$ da quantidade de NCO reativo do TDI. A amostra da graxa após a reação apresentou 1,64\% de grupos NCO reativos, evidenciando o consumo do mesmo durante a reação de obtenção da 
graxa. Os resultados obtidos caracterizam a reação como de alta eficiência, pode-se considerar que a estequiometria da reação está correta e que o processo é eficaz. Este método analítico é extremamente simples e eficaz para controle de qualidade na fabricação da graxa para determinar o consumo dos reagentes, ou seja, o fim da reação.

\subsubsection{Espectroscopia de infravermelho com transformada de Fourrier (FTIR)}

Foram realizados os espectros da tetrauréia pura em pó comparado com o espectro da graxa após a reação. A espectroscopia de FTIR mostrou uma banda em $3.307,9 \mathrm{~cm}^{-1}$ atribuída à vibração por estiramento do grupo dialquil $\mathrm{N}-\mathrm{H}$ e os picos entre 1.620 e $1280 \mathrm{~cm}^{-1}$, 1250 e $1240 \mathrm{~cm}^{-1}$ e $1730 \mathrm{~cm}^{-1}$ são característicos do grupo $\mathrm{C}=\mathrm{O}$ ligado a uma molécula de uréia. Essas características são observadas no espectro da figura 16 (DOBROWOLSKI; KOLOS; SADLEJ; MAZUREK, 2002).

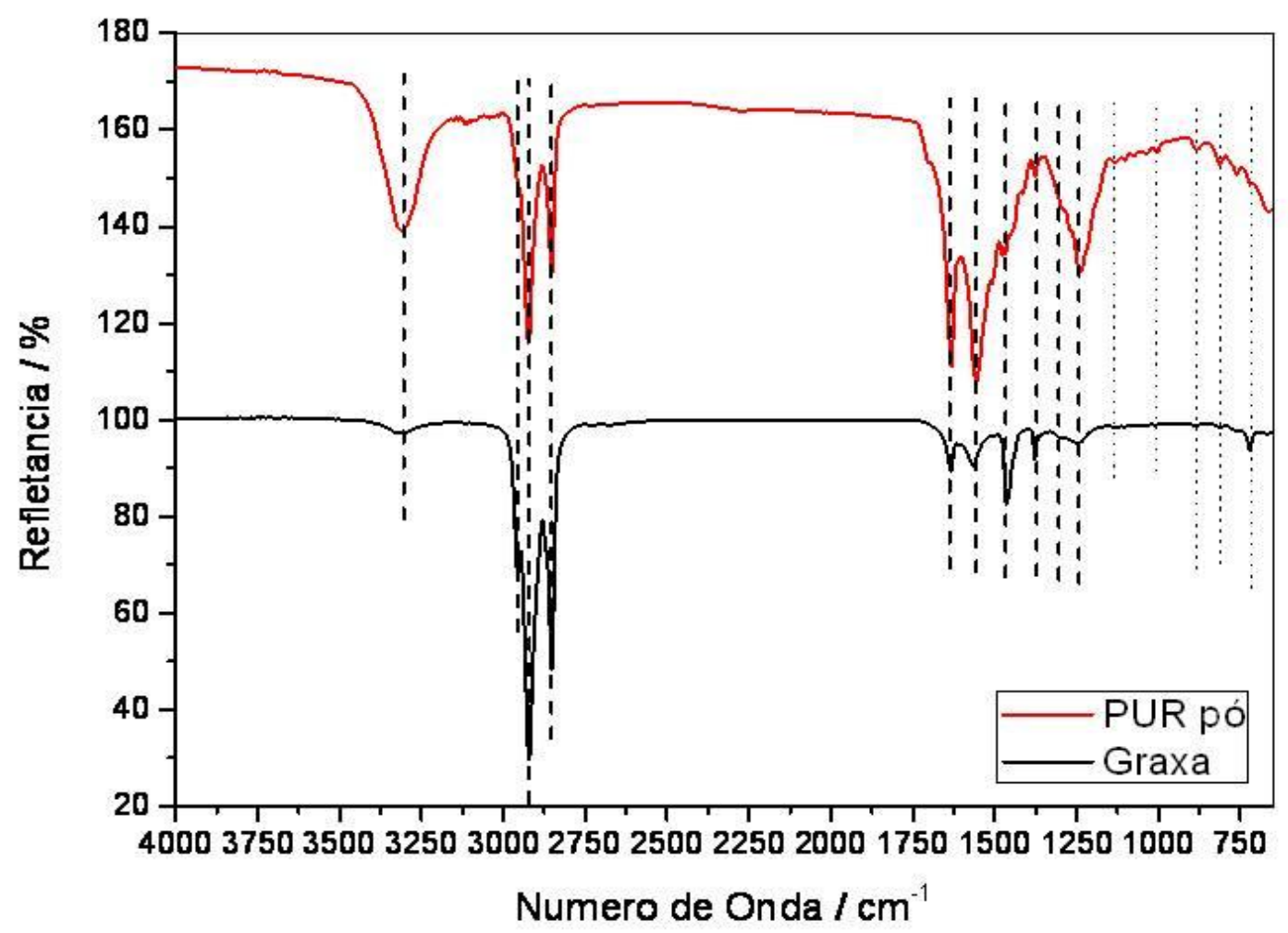

FIGURA 16 - Espectro de FTIR-ATR da graxa de tetrauréia em comparativo com a tetrauréia pura em pó. 
Foram comparados também os espectros dos reagentes utilizados na síntese da tetrauréia com o espectro da graxa após a reação, para evidenciar o consumo e a influência de cada um deles no espectro final da graxa.

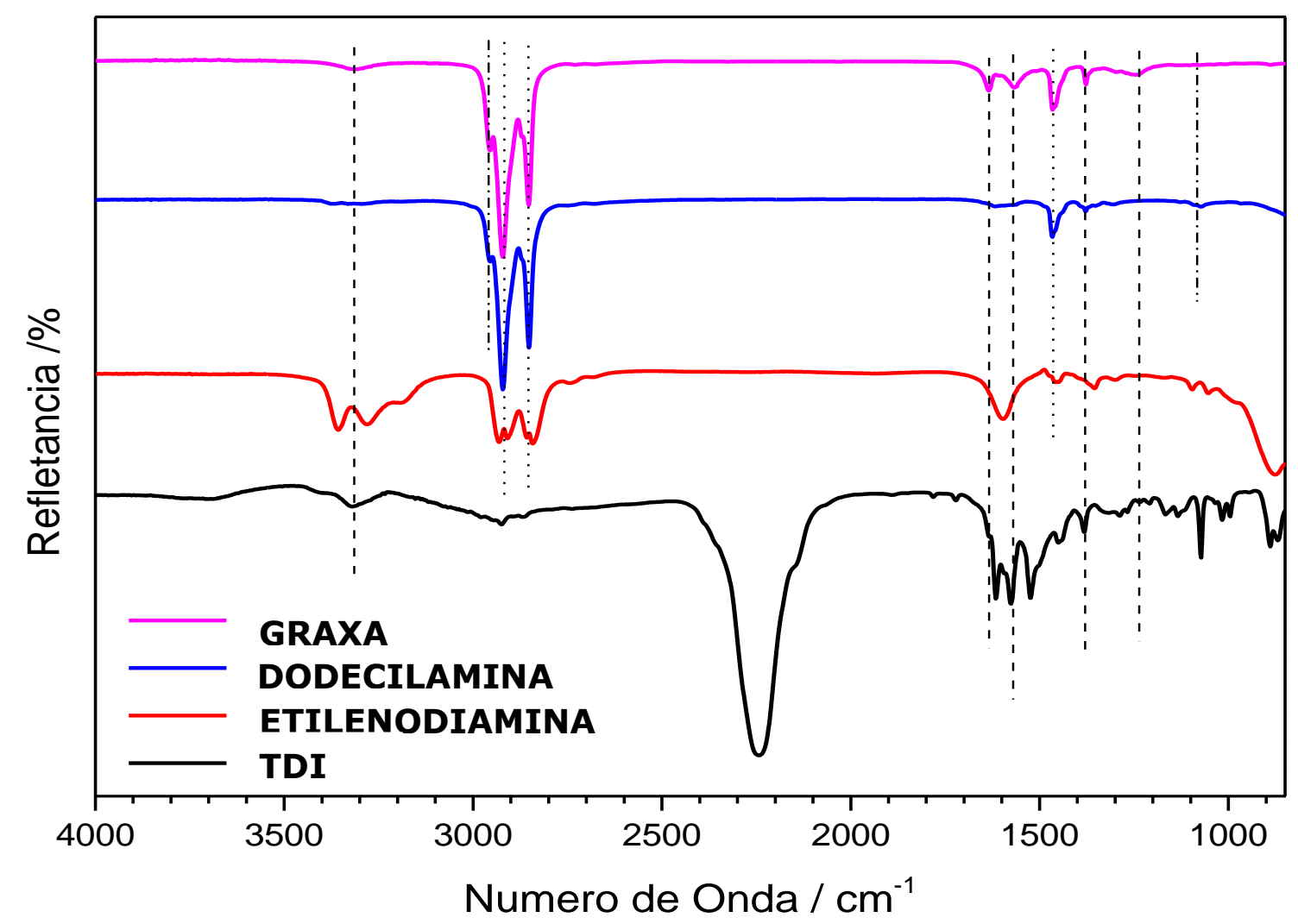

FIGURA 17 - Espectros de FTIR-ATR comparativos entre a dodecilamina, etilenodiamina, TDI e a graxa.

No espectro da figura 17, em relação ao consumo das aminas, é possível observar que elas foram consumidas pela diminuição das bandas entre $1200 \mathrm{~cm}^{-1} \mathrm{e}$ $900 \mathrm{~cm}^{-1}$ que são atribuídas ao estiramento da ligação $\mathrm{CN}$ em aminas alifáticas e em radicais alquila e arila (UNIVERSITY OF COLORADO, 2013).

Da mesma forma foi comparado o espectro de FTIR-ATR do isocianato utilizado na reação com o espectro da graxa obtida. $O$ consumo deste material foi evidenciado pelos picos entre 2240 e $2275 \mathrm{~cm}^{-1}$, característicos do grupo NCO livre na amostra, anteriormente existentes no espectro do diisocianato e ausentes no espectro da graxa de tetrauréia (BAUM, 2012). 
O espectro do fluido polialfaolefina (PAO) mostrado na figura 18 foi obtido para comparação com a graxa de tetrauréia, servindo como uma prova em branco ou "background" para os espectros característicos da tetrauréia, por ser apenas um veículo e não ser alterado ou consumido durante a reação.

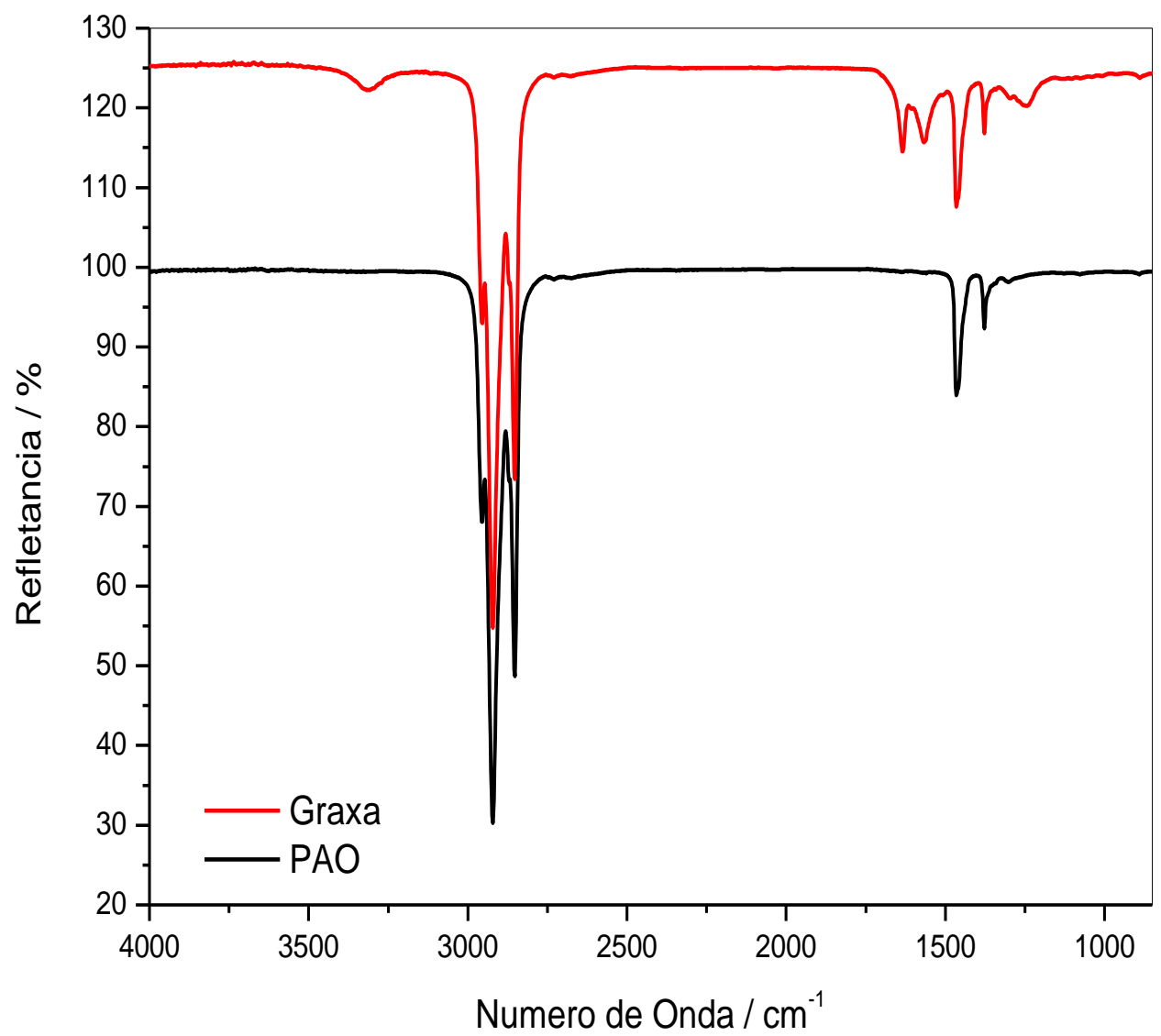

FIGURA 18 - Espectro de FTIR-ATR do fluido polialfaolefina em comparativo com a graxa de tetrauréia. 
Também foram analisadas em comparativo as amostras dos dois tipos de PTFE irradiados com uma amostra de PTFE virgem, não irradiado, conforme figura 19.
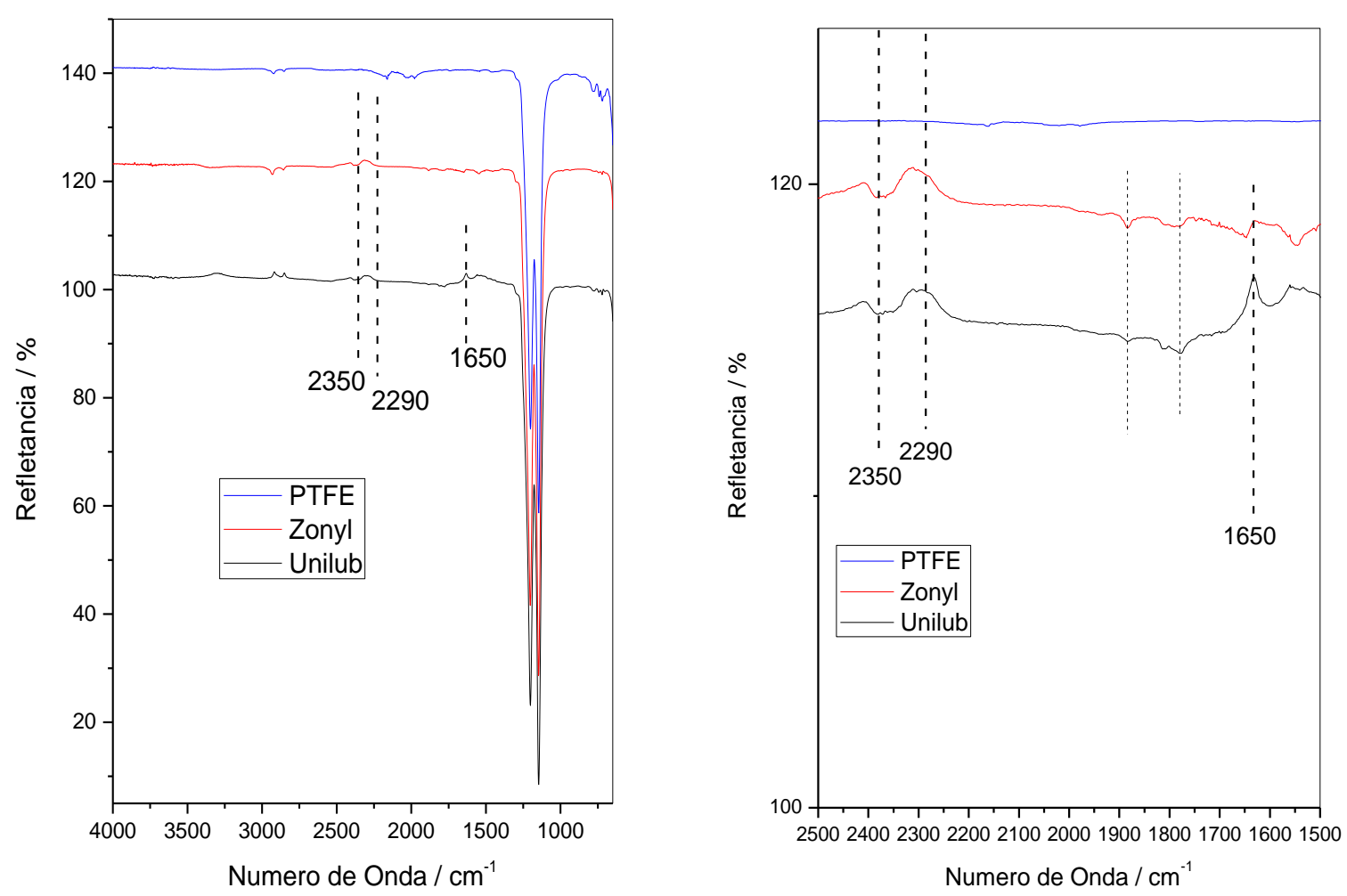

FIGURA 19 - Espectros de FTIR-ATR comparativos entre o PTFE virgem, PTFE irradiado por ultravioleta ( $\mathrm{PTFE}_{\mathrm{U}}$ ) e por radiação ionizante (PTFE $\mathrm{E}_{\mathrm{l}}$ ).

O Zonyl MP 1100 (PTFE $)$ e o Unilub L400 (PTFE $)$ apresentaram uma deformação na banda de aproximadamente $2290 \mathrm{~cm}^{-1}$, correspondente a vibração por estiramento da ligação C-C em compostos fluorados flúor (ALLAN; MAIER; MARTHALER; STADELMANN, 1978). A banda em $2350 \mathrm{~cm}^{-1}$ comum em todas as amostras analisadas pode ser atribuída à vibração por estiramento da ligação $C-C$ próxima a hidrogênio e. A banda em $1650 \mathrm{~cm}^{-1}$ presente apenas na amostra de Unilub L400 indica que o mesmo possui mais grupos oxidados que os demais, ou seja, um maior nível de degradação devido à radiação ionizante (BIERI; SCHMELZER, 1980). 


\subsubsection{Análise Elementar ( $\mathrm{AE})$}

O estudo da análise elementar mostrou a porcentagem de átomos de Carbono, Hidrogênio e Nitrogênio da molécula de tetrauréia obtida pela síntese das aminas com o isocianato. Pelo fato da molécula de tetrauréia ser composta apenas por átomos de Carbono, Hidrogênio, Nitrogênio e Oxigênio, e sabendo suas respectivas porcentagens, é possível quantificar átomos de oxigênio por exclusão. $\mathrm{O}$ cálculo da porcentagem de cada átomo da molécula de tetrauréia desse presente estudo fornece a porcentagem de Carbono de 68,5\%, Hidrogênio de 9,7\%, Nitrogênio de $13,9 \%$ e por exclusão o Oxigênio $7,9 \%$. Foi analisado o pó de tetrauréia obtido em solvente xileno e o pó de tetrauréia obtido em polialfaolefina e extraído pela lavagem da graxa base (isenta de PTFE) com solvente hexano, para avaliar se o veículo da reação altera o produto final, pois quanto mais viscoso o veículo, mais lentamente se sucede a reação. Os resultados encontrados são demonstrados pela tabela 7 .

TABELA 7 - Resultados da análise elementar do pó de tetrauréia obtido em solvente xileno e isento de PTFE.

\begin{tabular}{cc}
\hline $\begin{array}{c}\text { Pó de tetrauréia obtido em xileno } \\
\text { Elemento }\end{array}$ & $\%$ \\
\hline Carbono & 66,81 \\
Hidrogênio & 9,73 \\
Nitrogênio & 14,51 \\
\hline
\end{tabular}

As porcentagens obtidas por análise elementar e a porcentagem de Oxigênio por exclusão sendo de $8,95 \%$ mostram uma extrema proximidade com as porcentagens teóricas da molécula de tetrauréia, confirmando a formação do polímero esperado. As pequenas variações de valores podem ser devido a cadeia carbônica da monoamina utilizada variar entre 8 e 18 carbonos, mas predominando a cadeia carbônica de 12 carbonos. A segunda análise elementar foi realizada com o pó da tetrauréia retirado da graxa base (isenta de PTFE) por lavagens consecutivas com hexano para remoção da PAO. Os resultados estão descritos na tabela 8. 
TABELA 8 - Resultados da análise elementar do pó de tetrauréia retirado da graxa base por lavagem com hexano.

\begin{tabular}{cc}
\hline \multicolumn{2}{c}{ Pó de tetrauréia retirado por lavagem } \\
Elemento & $\%$ \\
\hline Carbono & 67,86 \\
Hidrogênio & 9,67 \\
Nitrogênio & 13,81
\end{tabular}

As porcentagens obtidas nessa segunda análise e, por exclusão a porcentagem de Oxigênio sendo de 8,66\%, também mostram uma extrema proximidade com as porcentagens teóricas da molécula de tetrauréia desejada, reafirmando a formação do polímero esperado. Estes resultados também mostraram que a mesma tetrauréia pode ser obtida em veículos de diferentes viscosidades como a PAO e o solvente xileno.

\subsubsection{Microscopia eletrônica de varredura (MEV)}

Foram realizadas micrografias em três tipos de amostras, a amostra a) graxa de tetrauréia em polialfaolefina aditivada com PTFE de $4 \mu \mathrm{m}$ (Unilub L400), amostra $b$ ) pó de tetrauréia retirado da graxa de obtida em polialfaolefina (isenta de PTFE) através da lavagem com hexano e amostra c) pó da tetrauréia obtido diretamente em solvente xileno. A figura 20 mostra as micrografias da amostra a) com o aumento, respectivamente, de 500, 1000 e 5000 vezes. 


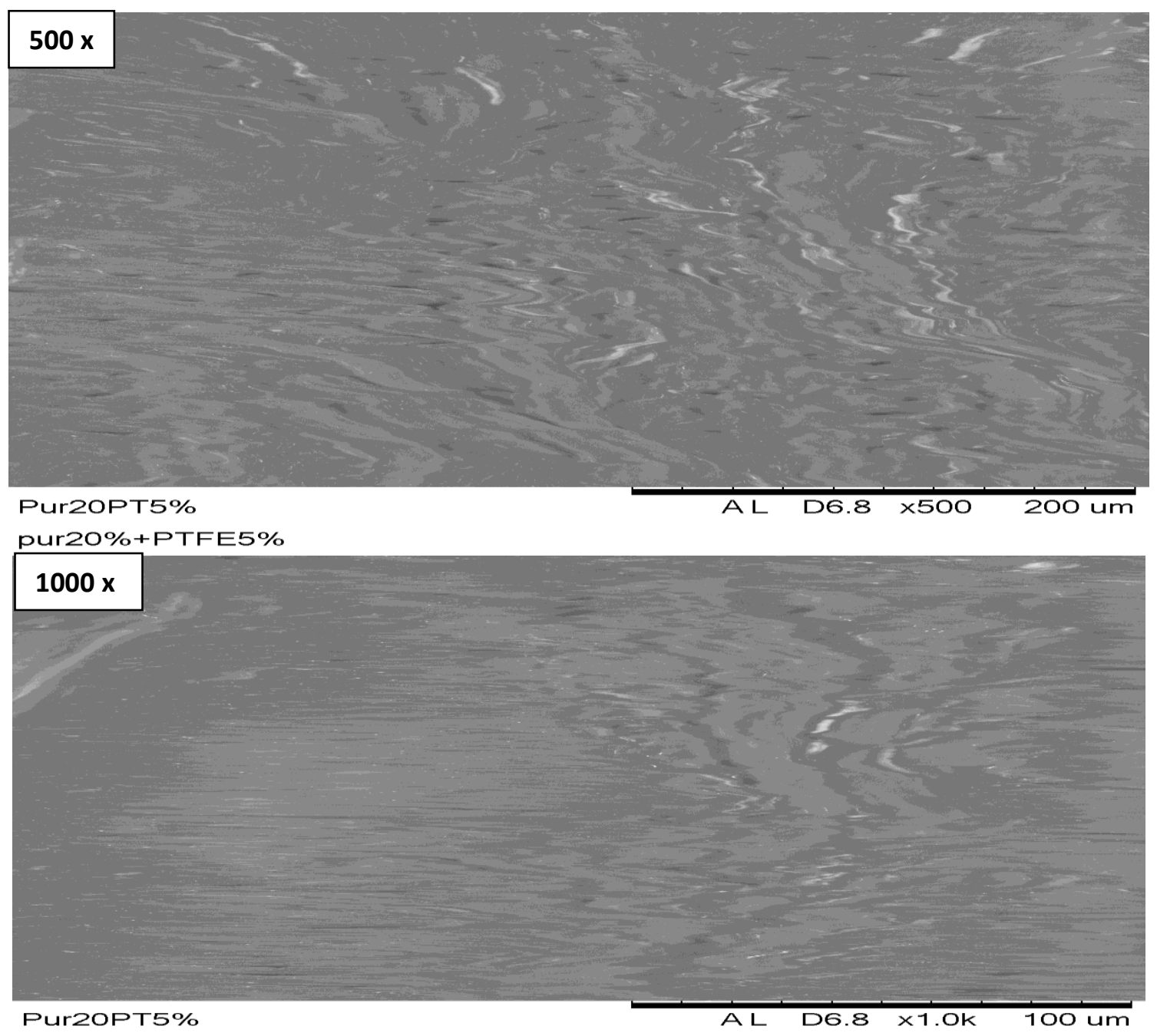

Pur2O\%+PTFE5\%

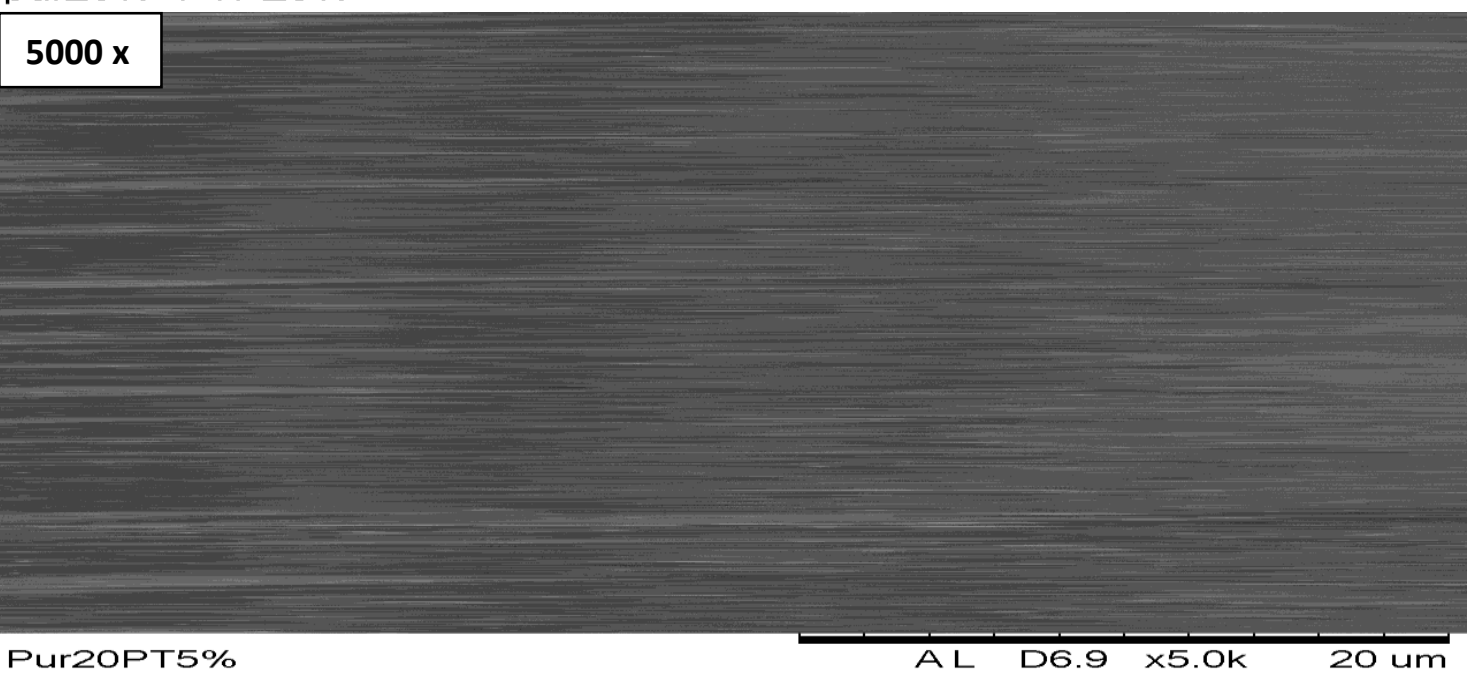

pur20\%+PTFE5\%

FIGURA 20 - Micrografias da amostra a) graxa de tetrauréia aditivada com PTFE de $4 \mu \mathrm{m}$ com aumento de 500, 1000 e 5000 vezes. 
O que se pode observar é uma imagem mais lisa com alguns aglomerados brancos de partículas de PTFE, o aspecto liso mostra que houve uma boa dispersão do polímero tetrauréia no fluido polialfaolefina, o que caracteriza compatibilidade entre espessante e fluido, observa-se também que conforme a imagem é ampliada o aspecto fica mais liso. A melhor dispersão da tetrauréia do que do PTFE é devido à tetrauréia ter sido obtida dentro do fluido polialfaolefina e o PTFE ter sido adicionado após a graxa pronta, o que atrapalha sua dispersão, pois o produto já esta no estado semi-sólido diminuindo seu poder de dissolução.

Para se obter uma imagem da tetrauréia pura, obtida em polialfaolefina, para estudo de sua superfície, foram realizadas diversas lavagens com solvente hexano na graxa base (isenta de PTFE), assim foi retirado todo fluido PAO e após a secagem se obteve um pó branco que foi submetido à análise. A figura 21, referente às micrografias da amostra $b$ ), apresenta um aspecto bem uniforme e liso, na imagem ampliada 5000 vezes pode-se observar alguns aglomerados brancos lisos, mas não foi possível verificar a superfície da tetrauréia, mostrando que as partículas da tetrauréia em polialfaolefina são extremamente pequenas (BAUM, 2009). 


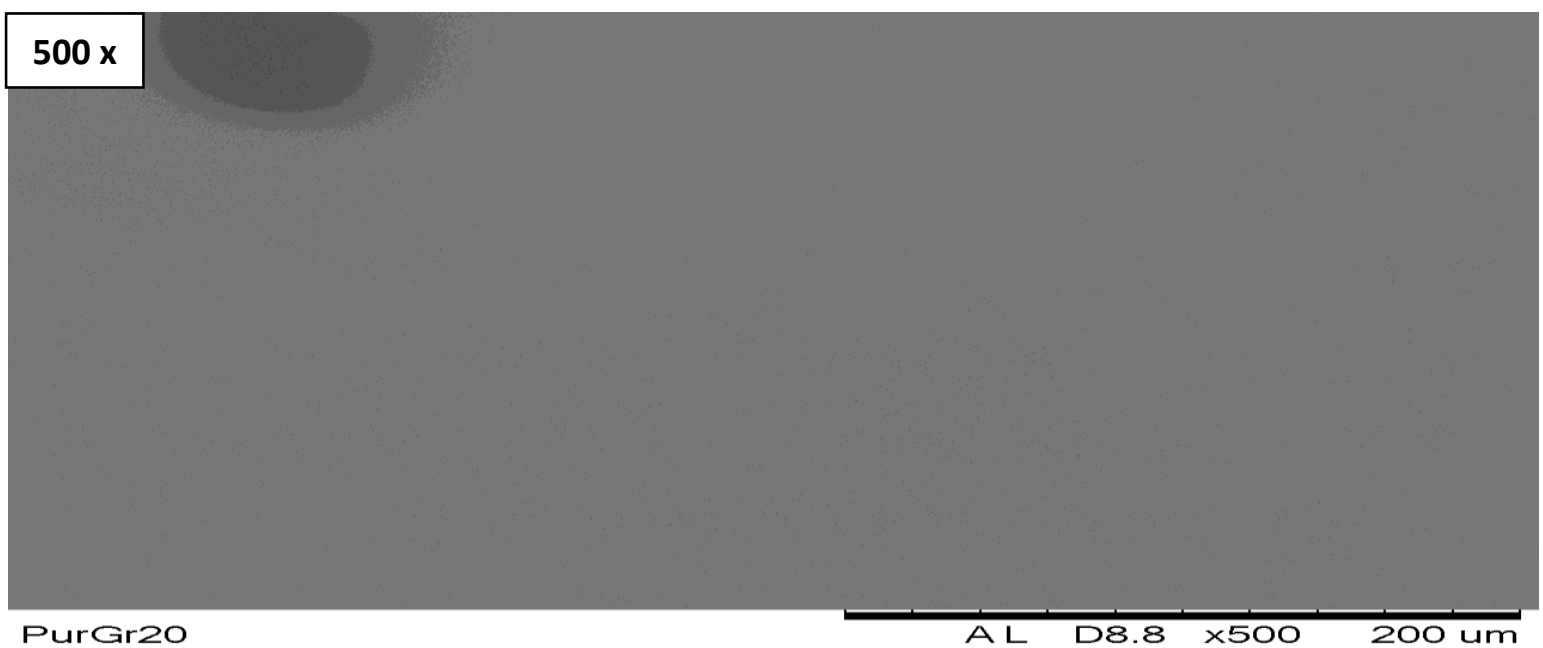

purGraxa20\%

$1000 \mathrm{x}$

PurGrzo

A L

D6.3

$\times 1 . \mathrm{OK}$

$100 \mathrm{um}$

purGraxa20\%

$5000 x$

Purgr20

A L DG.1 $\times 5.0 K$

$20 \mathrm{um}$

purGraxa20\%

FIGURA 21 - Micrografias ampliadas 500, 1000 e 5000 vezes da amostra b) pó de tetrauréia retirada da graxa obtida em polialfaolefina (isenta de PTFE) através da lavagem com hexano. 
Tentou-se obter a mesma tetrauréia estudada diretamente em solvente orgânico xileno, a reação foi extremamente rápida e exotérmica, após 1 hora e 30 minutos a tetrauréia foi processada em um moinho de três rolos e o pó obtido foi submetido à secagem a $100^{\circ} \mathrm{C}$ durante um período de $3 \mathrm{~h}$, após a secagem o pó foi triturado novamente em um almofariz e este pó foi analisado, conforme a figura 22 , que representa as micrografias ampliadas, respectivamente, em 500, 1000 e 5000 vezes. 

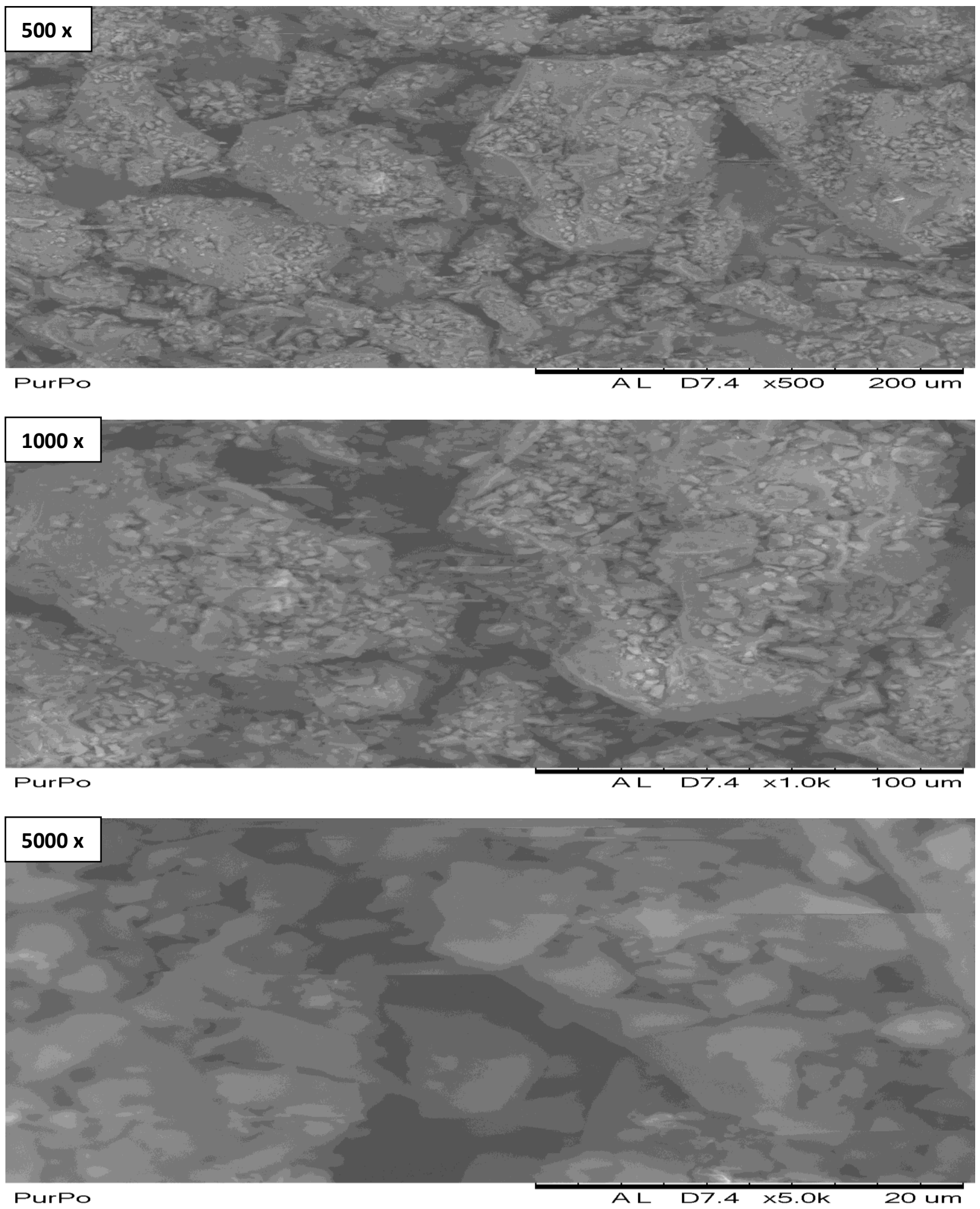

FIGURA 22 - Micrografias da amostra c) pó da tetrauréia obtido diretamente em solvente xileno (isento de PTFE) ampliadas 500, 1000 e 5000 vezes. 
As microgafrias da amostra c) mostram partículas de diversos tamanhos bem compactadas e com a superfície lisa, o que provavelmente não representa a estrutura da tetrauréia quando obtida em polialfaolefina, pois uma estrutura como essa não teria um poder espessante, já que o espessante age adsorvendo o fluido em sua estrutura emaranhada e porosa. Estruturas de graxa de poliuréia são geralmente de três tipos fibrosas, espiral e macarrão. O que determina a estrutura da graxa de poliureia é a razão molar dos ingredientes, a temperatura e o tempo de processamento, se a massa é processada a uma temperatura elevada a possibilidade de obter a estrutura tipo macarrão é elevada. A estabilidade a pressão e a estabilidade ao cisalhamento são determinadas pela estrutura do espessante, uma boa combinação de material de fibras e em espiral é necessária para uma boa estabilidade a pressão e a estabilidade ao cisalhamento.

Uma hipótese para as superfícies de tetrauréia aparentarem serem diferentes é que a alta viscosidade da PAO torna a reação mais lenta e por sua alta compatibilidade ela é adsorvida nos poros da tetrauréia e ali se mantém impedindo fisicamente a compactação das partículas. Quando a tetrauréia é obtida em xileno, a reação é muito rápida e o solvente por ser muito volátil e pouco viscoso, evapora assim que a temperatura da reação se eleva e deixa os poros da tetrauréia livres para se compactarem. Como demonstrado anteriormente pela análise elementar, ambas tetrauréias possuem a mesma fórmula molecular, podendo ser obtidas em fluidos de diferentes viscosidades, mas não com a mesma forma estrutural, como comprovado pela análise de MEV.

\subsubsection{Calorimetria Exploratória Diferencial (DSC)}

Para estudar as diferenças estruturais entre o PTFE irradiado por ultravioleta e radiação ionizante, os polímeros foram submetidos ao teste de Calorimetria Exploratória Diferencial (DSC). Para calcular $\circ \mathrm{W}_{\mathrm{c}}$ (porcentagem cristalina) foi utilizada a seguinte fórmula:

$$
\mathrm{W}_{\mathrm{c}}=\left(\Delta \mathrm{H}_{\mathrm{f}} / \Delta \mathrm{H}_{\mathrm{f} 100}\right) \times 100
$$


Onde $\Delta \mathrm{H}_{\mathrm{f}}$ é a alteração na entalpia de fusão da amostra e $\Delta \mathrm{H}_{\mathrm{f} 100}$ é a entalpia de fusão de um polímero $100 \%$ cristalino. Para o PTFE, o $\Delta \mathrm{H}_{\mathrm{f} 100}$ é 82,9 (A. GERALDES, 2009).

TABELA 9 - Resultados da análise de DSC nas amostras de PTFE.

\begin{tabular}{cccc}
\hline Amostra & $\mathbf{T}_{\mathbf{f}}\left({ }^{\circ} \mathbf{C}\right)$ & $\Delta \mathbf{H}_{\mathbf{f}}\left(\mathbf{J ~ g}^{-1}\right)$ & $\mathbf{W}_{\mathbf{c}}(\%)$ \\
\hline PTFE Prístino & 331 & 38 & 46 \\
PTFE por radiação ultravioleta & 311 & 56 & 68 \\
PTFE por radiação ionizante & 313 & 63 & 76
\end{tabular}

O PTFE sofre cisão de cadeia se submetido à radiação ionizante. Essas cadeias menores apresentam a mesma estrutura química básica do PTFE virgem e maior mobilidade devido a sua menor massa molar. Portanto, apresentam maior possibilidade de alinharem suas cadeias permitindo um aumento da cristalinidade após a irradiação em baixas doses (GERALDES, 2009).

Com base nos resultados da análise de DSC (TABELA 9), é possível observar que o PTFE que foi processado por radiação ionizante apresentou um maior valor de cristalinidade e uma temperatura de fusão $\left(T_{f}\right)$ equivalente a do PTFE processado por radiação ultravioleta. Esses resultados sugerem que apesar de ambas amostras apresentarem cristais com populações de lamelas de mesma dimensão (pois apresentam a mesma $T_{f}$ ), o PTFE que foi processado por radiação ionizante sofreu uma maior cisão de cadeia pois tem cristalinadade consideravelmente maior. Sabe-se que a cada cisão da cadeia de uma molécula polimérica ocorre a geração de insaturações e radicais livres que podem se combinar com oxigênio disponível no sistema gerando um polímero altamente funcionalizado.

\subsection{Estudo das características funcionais da graxa de tetrauréia}

Estudos sobre as propriedades funcionais da graxa espessada com a tetrauréia obtida foram realizados a fim de determinar a aplicabilidade da graxa em processos industriais. As características mais desejáveis para uma graxa lubrificante são: estabilidade, alto ponto de gota, resistência a cargas elevadas e ao desgaste por atrito. 


\subsubsection{Quatro Esferas}

\subsubsection{Solda e escoriação}

No estudo da solda em equipamento de quatro esferas foram comparadas as amostras das graxas de poliuréia pura e amostras da mesma graxa aditivada com ambos tipos de politetrafluoretileno (PTFE) irradiados com partículas de $4 \mu \mathrm{m}$. Os resultados estão descritos na tabela 10.

TABELA 10 - Resultados do ensaio de quatro esferas - solda na graxa pura, aditivada com PTFE processado por radiação iniozante e ultravioleta.

\begin{tabular}{cccc}
\hline Graxa & Passa & Desgaste da Calota & Solda \\
\hline Pura & $126 \mathrm{~kg}$ & $2,383 \mathrm{~mm}$ & $160 \mathrm{~kg}$ \\
$5 \%$ de PTFE & $500 \mathrm{~kg}$ & $2,984 \mathrm{~mm}$ & $620 \mathrm{~kg}$ \\
$5 \%$ de PTFE & $250 \mathrm{~kg}$ & $2,079 \mathrm{~mm}$ & $315 \mathrm{~kg}$ \\
\hline
\end{tabular}

i- Processado por radiação ionizante; u- Processado por radiação ultravioleta.

Os resultados mostraram que a graxa pura apresenta uma resistência razoável à cargas elevadas e que a presença de PTFE eleva essa resistência, sendo que o PTFE processado por radiação ionizante eleva ainda mais essa resistência do que o PTFE irradiado por ultravioleta, o que caracterizou o PTFE também como agente de extrema pressão.

O PTFE Unilub L400 elevou em quase quatro vezes a resistência à pressão e cisalhamento da graxa. Analisando a escoriação da superfície lubrificada, os resultados mostraram que mesmo a carga aplicada sobre as esferas sendo quase quatro vezes maior do que a carga aplicada na graxa pura, a escoriação na superfície metálica não se elevou proporcionalmente, o que demonstra que provavelmente se medida a escoriação da superfície sobre a carga de $126 \mathrm{~kg}$, como feito na graxa pura, o valor da escoriação seria menor.

Graxas a base de uréia apresentam excelentes propriedades antidesgaste devido a trabalharem em regime de lubrificação limite, que é quando a resistência ao movimento se deve às moléculas depositadas nas superfícies em contato e não apenas pelo filme formado pelo lubrificante. Com demonstrado pelas análises de caracterização, o PTFE processado por radiação ionizante (Unilub L400) 
possui uma maior cristalinidade e um teor maior de grupos terminais oxigenados que reduzem o atrito por possuírem uma forte afinidade com a superfície do metal. Sob altas temperaturas ou pressões, estes grupos oxigenados ligam-se quimicamente com a superfície metálica formando uma película protetora que cobre as asperezas das superfícies metálicas tornando-as mais deslizantes evitando os danos do cisalhamento (BARBOSA, 2013).

O tamanho das partículas de um lubrificante sólido também influencia diretamente a sua resistência à pressão, pois as partículas devem ser pequenas o suficiente para penetrarem nos poros da superfície lubrificada e não podem ser tão pequenas a ponto de fragilizar a estrutura da molécula diminuindo sua resistência a pressão e ao cisalhamento, portanto o tamanho de $4 \mu \mathrm{m}$ se mostrou adequado para esta aplicação.

\subsubsection{Desgaste}

De acordo com os resultados mostrados na tabela 11, foi possível observar que os valores de desgaste foram um pouco maiores quando adicionado o lubrificante sólido PTFE à graxa, porém são muito próximos, não chegando a variar nem $1 \mathrm{~mm}$ entre si. A diferença entre o $\mathrm{PTFE}_{\mathrm{i}}$ e o $\mathrm{PTFE}_{\mathrm{u}}$ é de $0,036 \mathrm{~mm}$, mostrando que referente a característica antidesgaste, eles agem praticamente iguais.

TABELA 11 - Resultados do ensaio de quatro esferas - desgaste com a graxa de tetrauréia pura e aditivada com PTFE processado por radiação ionizante e ultravioleta.

\begin{tabular}{cc}
\hline Graxa & Desgaste da Calota \\
\hline Pura & $0,448 \mathrm{~mm}$ \\
$5 \%$ de PTFE & $0,511 \mathrm{~mm}$ \\
$5 \%$ de PTFE & $0,475 \mathrm{~mm}$
\end{tabular}

i- Processado por radiação ionizante; u- Processado por radiação ultravioleta.

Estes resultados mostram que quando se aplica uma carga baixa de pressão, a poliuréia pura já apresenta um ótimo desempenho. Na lubrificação com filme de óleo (Hidrodinâmica e Elastohidrodinâmica) a resistência ao movimento se deve inteiramente a viscosidade da camada lubrificante interposta, já no caso da 
poliuréia que trabalha em regime de lubrificação limite, regime intermediário entre lubrificação fluida e seca, a espessura mínima da camada lubrificante para mancais comuns pode ser tomada igual a 10 micra, ou seja, a poliuréia pura já apresenta uma camada lubrificante, que se forma pela sua espécie química, suficiente para baixas cargas, o lubrificante sólido é excelente quando as pressões entre as duas superfícies móveis são muito elevadas, chegando-se a um ponto no qual não é mais possível manter uma película lubrificante, havendo ruptura da película em alguns pontos, há nestas condições uma combinação de atritos sólidos e fluidos, aumentando o atrito, por esse motivo o PTFE foi mais eficiente quando testado sobre alta pressão, no teste de solda (HIRONAKA, 1984).

Quando comparamos os valores obtidos com as graxas mais utilizadas no mercado percebemos que estes valores de desgaste são extremamente baixos, classificando esta graxa como um lubrificante com excelentes características antidesgaste, pois a poliuréia apresenta uma melhor aderência a superfícies metálicas do que graxas a base de sabão de metálico. Em graxas de sabão, o íon metálico pode atuar como um catalisador para a oxidação, a ausência destes íons na poliuréia proporciona a este tipo de graxa, excelente desempenho sob temperaturas elevadas.

TABELA 12 - Resultados do ensaio de quatro esferas - desgaste em graxas de lítio, cálcio e diuréia

\begin{tabular}{cc}
\hline Tipo de espessante & Desgaste da Calota \\
\hline Lítio & $0,595 \mathrm{~mm}$ \\
Cálcio & $0,623 \mathrm{~mm}$ \\
Diuréia & $0,730 \mathrm{~mm}$
\end{tabular}

O estudo do teste de quatro esferas solda mostrou que o PTFE mais indicado para a graxa de tetrauréia foi o PTFE processado por radiação ionizante, por apresentar mais grupos oxidados, garantindo assim uma melhor ancoragem da graxa nas superfícies metálicas e o teste de desgaste demonstrou o excelente desempenho anti-desgaste da graxa de tetrauréia pura e que a utilização de PTFE não interfere significativamente nos resultados. 


\subsubsection{Ponto de Gota}

Foi estudada a temperatura máxima que a graxa poderia ser submetida até que gotejasse, caracterizando seu ponto de gota, foram realizados diversos ensaios confirmando os resultados descritos na tabela 13.

TABELA 13 - Resultados do ensaio de ponto de gota na graxa de tetrauréia pura e aditivada com PTFE de $4 \mu \mathrm{m}$.

\begin{tabular}{cc}
\hline Graxa & Ponto de gota \\
\hline Tetrauréia pura $^{\circ}$ & $255^{\circ} \mathrm{C}$ \\
$5 \%$ de PTFE & $260^{\circ} \mathrm{C}$ \\
$5 \%$ de PTFE & $258^{\circ} \mathrm{C}$ \\
\hline Lítio & $180^{\circ} \mathrm{C}$ \\
Cálcio & $250^{\circ} \mathrm{C}$ \\
\hline
\end{tabular}

A temperatura tem grande influência no desempenho da graxa lubrificante, já que sob altas temperaturas a graxa pode oxidar se tornando abrasiva, também podem ocorrer grandes variações de consistência alterando a espessura do filme lubrificante e a graxa pode até escorrer deixando as partes da máquina sem lubrificação. As graxas comuns do mercado têm seus pontos de gota em torno de $180^{\circ} \mathrm{C}$, o que atende os processos comuns de lubrificação, porém graxas consideradas especiais precisam ter um ponto de gota de no mínimo $250^{\circ} \mathrm{C}$, as graxas a base de uréia já são conhecidas por seu alto ponto de gota, chegam até a serem consideradas sem ponto de gota, já que independente se a graxa suportar mais que $250^{\circ} \mathrm{C}$, os outros componentes da graxa e materiais lubrificados sofreriam decomposição (KINOSHITA; SEKIYA; MISHIMA, 1990).

A graxa de tetrauréia do presente estudo apresentou um ponto de gota de $260^{\circ} \mathrm{C}$ mostrando que seu fluido lubrificante tem alto índice de viscosidade, não alterando significativamente sua viscosidade pela variação de temperatura, e alta compatibilidade com o espessante, o que promove alta resistência a temperaturas elevadas, podendo ser tranquilamente aplicada em pontos de lubrificação submetidos a temperaturas de até $240^{\circ} \mathrm{C}$. A presença de PTFE na graxa teve um impacto positivo mostrando-se compatível com o fluido e com o espessante tornando a graxa mais estável sob temperaturas elevadas. 


\subsubsection{Separação de óleo}

A porcentagem de óleo que migra da graxa para sua superfície, mostra a estabilidade do fluido com o espessante sob temperatura elevada $\left(100^{\circ} \mathrm{C}\right)$ e repouso. Quando há a separação de óleo da graxa, o óleo se acumula em sua superfície, causando uma variação de consistência, tornando a parte superior da graxa mais macia e a parte inferior mais consistente o que pode causar danos ao equipamento. A graxa de tetrauréia do presente estudo mostrou os seguintes resultados descritos na tabela 14.

TABELA 14 - Resultados do ensaio de separação de óleo na graxa de tetrauréia pura e aditivada com PTFE

\begin{tabular}{cc}
\hline Graxa & Separação de óleo (\%) \\
\hline Tetrauréia pura & 1,87 \\
$5 \%$ de PTFE & 1,75 \\
$5 \%$ de PTFE & 1,83
\end{tabular}

O fluido lubrificante da graxa de tetrauréia representa $70 \%$, em massa, de sua composição, o limite máximo aceito de separação de óleo é de $5 \%$, de acordo com os resultados a graxa apresentou baixa separação de óleo, o que não alteraria sua consistência, reafirmando a estabilidade e compatibilidade dos polímeros polialfaolefina e tetrauréia. A presença do aditivo PTFE, por também agir como um espessante secundário, ajudando a reter o fluido lubrificante na graxa evitando que o óleo migre para superfície, representando outro benefício ao seu uso (KINOSHITA; SEKIYA; MISHIMA, 1990).

\subsubsection{Determinação da consistência pela penetração do cone}

Foi determinada a consistência da graxa de tetrauréia pela penetração de um cone de dimensões, massa e acabamento definidos. De acordo com a penetração encontrada é possível verificar na tabela 15 elaborada pelo NLGI (National Lubricating Grease Institute) a consistência que a graxa lubrificante se enquadra. As análises de consistência não trabalhada e trabalhada 10.000 vezes foram realizadas apenas na amostra aditivada com o PTFE processado por radiação 
ionizante por ter sido selecionado como o mais adequado pelos testes anteriores, descritos nos itens 5.2.1, 5.2.2 e 5.2.3.

TABELA 15 - Classificação NLGI para consistência de graxas lubrificantes

\begin{tabular}{cc}
\hline Consistência NLGI & Faixa de penetração \\
\hline 000 & $445-475$ \\
00 & $400-430$ \\
0 & $355-385$ \\
1 & $310-340$ \\
2 & $265-295$ \\
3 & $220-250$ \\
4 & $175-205$ \\
5 & $130-160$ \\
6 & $85-115$ \\
\hline
\end{tabular}

\subsubsection{Penetração não trabalhada}

A análise da penetração da graxa em repouso foi realizada repetidas vezes durante um período de 30 dias conforme a tabela 16.

TABELA 16 - Valores de penetração não trabalhada da graxa de tetrauréia

\begin{tabular}{cccc}
\hline Dia & Penetração & Consistência & Variação \\
\hline Inicial & $299 \mathrm{~mm} / 10$ & $1 / 2$ & - \\
2 & $280 \mathrm{~mm} / 10$ & $1 / 2$ & - \\
5 & $275 \mathrm{~mm} / 10$ & 2 & $5 \mathrm{~mm} / 10$ \\
10 & $272 \mathrm{~mm} / 10$ & 2 & $8 \mathrm{~mm} / 10$ \\
15 & $268 \mathrm{~mm} / 10$ & 2 & $12 \mathrm{~mm} / 10$ \\
20 & $268 \mathrm{~mm} / 10$ & 2 & $12 \mathrm{~mm} / 10$ \\
25 & $268 \mathrm{~mm} / 10$ & 2 & $12 \mathrm{~mm} / 10$ \\
30 & $268 \mathrm{~mm} / 10$ & 2 & $12 \mathrm{~mm} / 10$
\end{tabular}

A penetração inicial é desconsiderada já que após a síntese de tetrauréia, assim como após a adição de PTFE a graxa foi processada em um moinho de três rolos diversas vezes até a perfeita dispersão dos polímeros, o que gerou um 
amaciamento momentâneo da graxa, sendo apenas considerada a penetração após 2 dias de sua fabricação e processamento. Analisando os valores encontrados foi possível observar que a graxa se manteve estável mesmo estando em repouso durante 30 dias, já que a variação de penetração não alterou sua faixa de consistência. A estabilidade de consistência também mostra que a reação entre as aminas e o isocianato cessou, pois caso a reação não houvesse cessado, ocorreria a formação de mais tetrauréia, agindo como espessante, o que elevaria a consistência da graxa (PRATT, 1995).

\subsubsection{Penetração trabalhada}

Seguindo a mesma norma da penetração não trabalhada, foi estudada a penetração da graxa de tetrauréia com o PTFE Unilub L400 quando trabalhada 10.000 vezes com o trabalhador de graxa padronizado acoplado ao equipamento, conforme a figura 23 , porém sem necessidade de repetir a medição após períodos determinados, pois a penetração trabalhada é medida uma única vez após uma determinada quantidade de trabalho na graxa.

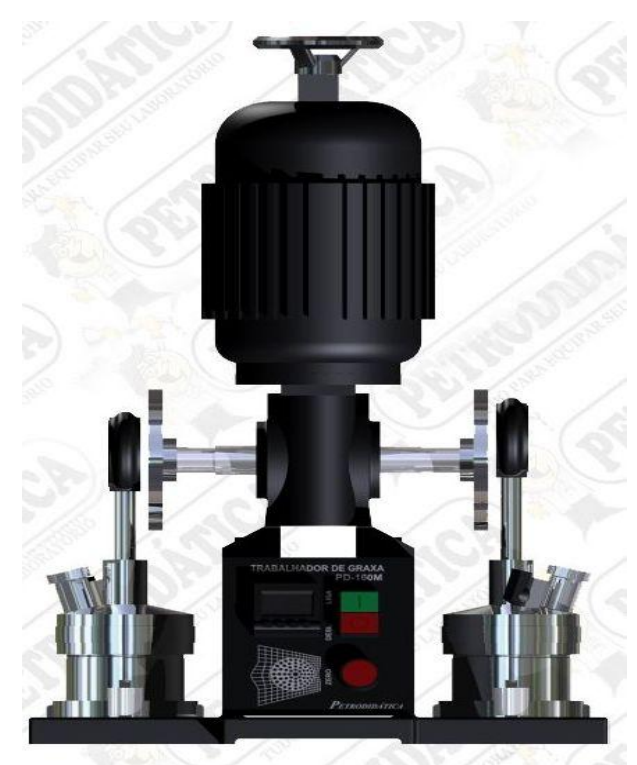

FIGURA 23 - Trabalhador automático de graxa lubrificante para análise de penetração por cone.

O resultado obtido pela penetração trabalhada 10.000 vezes da graxa de tetrauréia aditivada com PTFE esta descrito na tabela 17 em comparativo com a 
penetração não trabalhada para análise da variação de consistência da graxa quando em repouso e quando em trabalho.

TABELA 17 - Resultado de penetração da graxa de tetrauréia aditivada com PTFE trabalhada 10.000 vezes.

\begin{tabular}{cccc}
\hline Graxa de Tetrauréia & Penetração & Consistência & Variação \\
\hline Não trabalhada & 268 & 2 & - \\
Trabalhada 10.000x & 300 & $2 / 1$ & 32
\end{tabular}

A estabilidade física da graxa sob trabalho revela que a cadeia do espessante é resistente ao cisalhamento e esmagamento, também mostra que há uma excelente compatibilidade com o fluido lubrificante, já que o espessante está apenas disperso no fluido e que sua superfície tem que ser porosa o suficiente para adsorver o óleo e ser compatível para se manter estável em condições de trabalho. A graxa de tetrauréia estudada se mostrou extremamente estável, se mantendo praticamente na mesma consistência mesmo após ser 10.000 vezes trabalhada, a variação de $32 \mathrm{~mm} / 10$ é considerada normal e baixa, não causando danos ao equipamento lubrificado.

As graxas de poliuréia normalmente não são indicadas para sistemas centralizados pela sua característica de tixotropia quando em repouso, ou seja, há um aumento de consistência da graxa em repouso o que pode causar problemas para seu bombeamento até o equipamento a ser lubrificado, no estudo realizado com a graxa de tetrauréia do presente trabalho, observou-se uma melhoria significativa nesse aspecto, a graxa se manteve absolutamente estável após 15 dias em repouso e sua variação inicial foi pequena e bem próxima das graxas comuns do mercado (KINOSHITA; SEKIYA; MISHIMA, 1990).

\subsubsection{Teste prático em rolamentos}

O teste prático em rolamentos é uma técnica essencial para testar uma graxa antes de inseri-la no mercado, pois simula exatamente as condições encontradas em campo. Nesse estudo foram testadas as duas graxas de tetrauréia, uma aditivada com PTFE processado por radiação ionizante e outra com o PTFE processado por ultravioleta, em comparativo foram testadas duas graxas a base de 
poliuréia de fabricantes de referência no mercado, muito conhecidas e utilizadas no mercado.

No primeiro rolamento da esquerda da foto abaixo, foi aplicada a graxa POLIREX EM da multinacional Mobil, no segundo rolamento foi aplicada a graxa de tetrauréia deste estudo aditivado com o PTFE

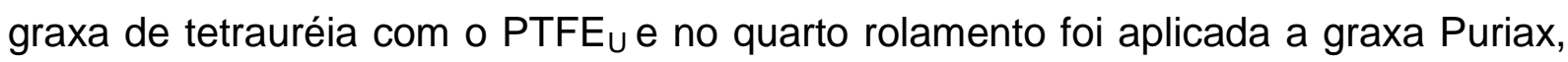
da empresa Lumobras. Foram aplicadas $5 \mathrm{~g}$ de cada graxa em um rolamento novo da marca ZKL, os rolamentos foram fechados, o equipamento montado e o teste se iniciou com a rotação em $2000 \mathrm{rpm}$ e a temperatura $200^{\circ} \mathrm{C}$, conforme figuras 24,25 e 26.

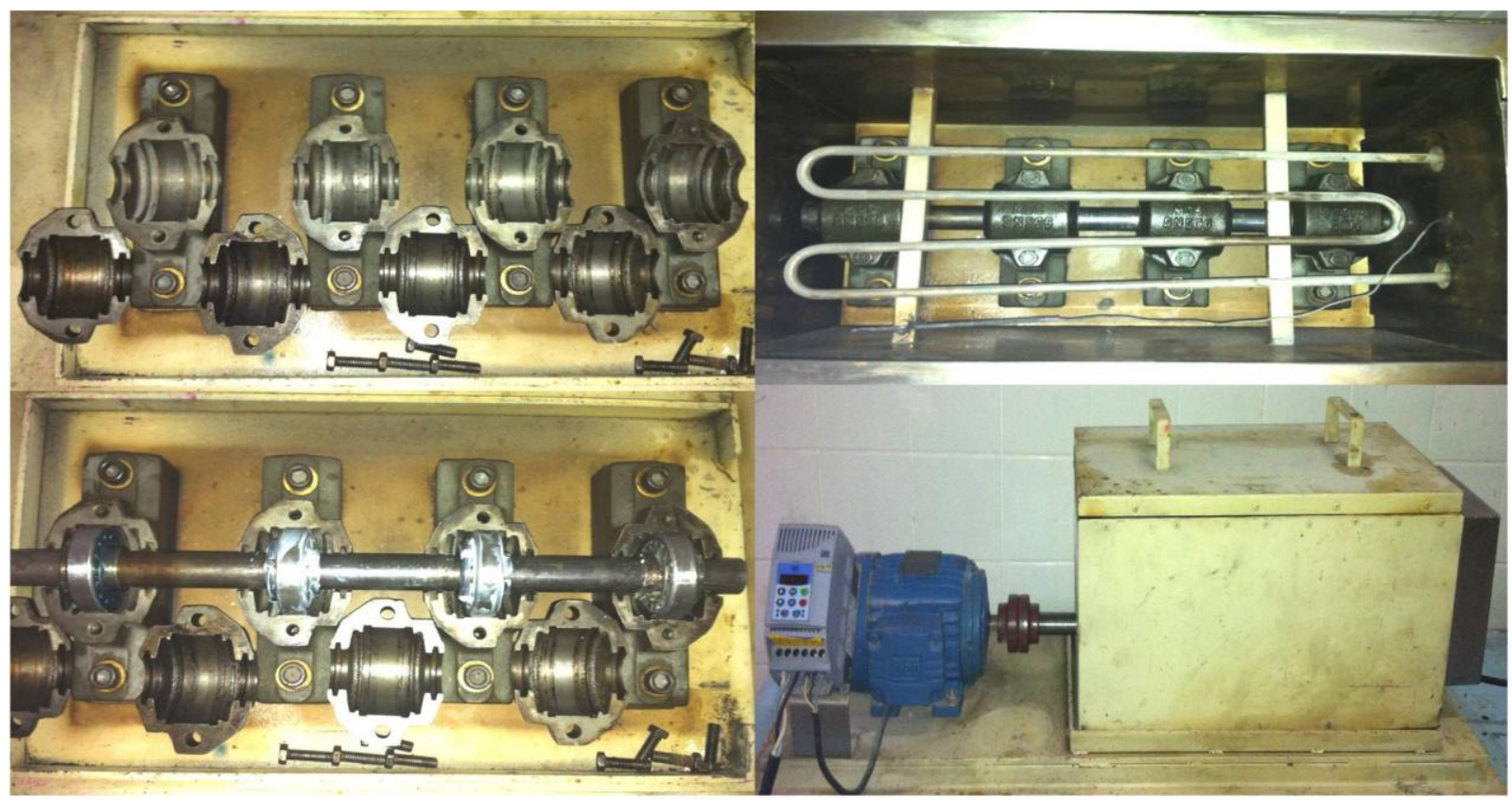

FIGURA 24 - Fotografias da montagem do teste de rolamentos. 
O teste correu por $24 \mathrm{~h}$ e após este período foi realizada a primeira leitura das condições dos rolamentos, conforme figura 25.

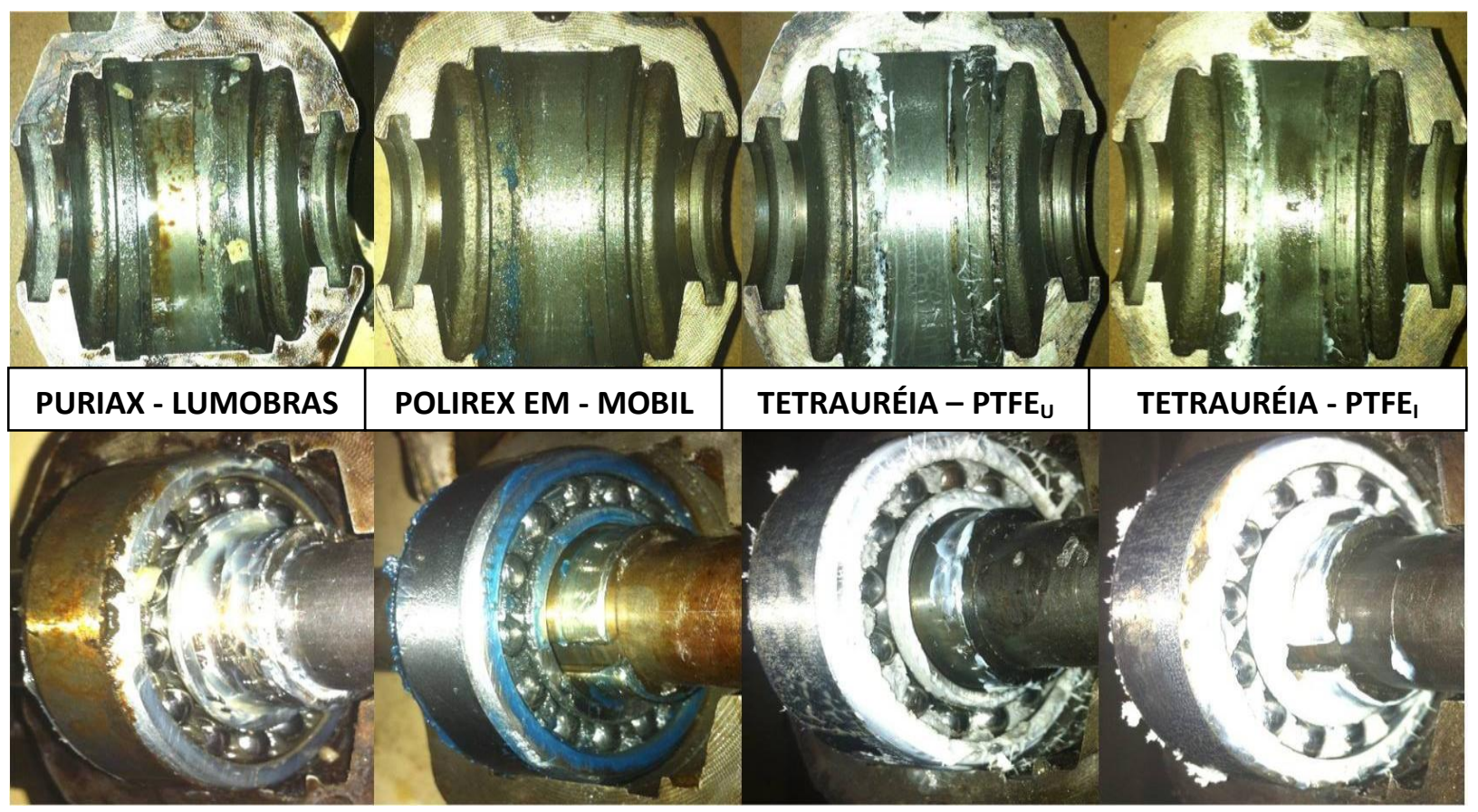

FIGURA 25 - Fotografias dos rolamentos após 24 horas de teste.

Todos os rolamentos estavam em perfeito estado, as graxas Polirex EM, tetrauréia com $\mathrm{PTFE}_{\cup}$ e tetrauréia com PTFE $\mathrm{P}_{\text {e }}$ estavam em condições normais, sendo que a tetrauréia com PTFE, foi a que mais se manteve aderida ao rolamento e a graxa Puriax da Lumobras foi a que mais se desprendeu do rolamento e apresentou bastante oxidação, mudando sua cor para castanho escuro. 
O teste foi reiniciado por mais 48 horas, totalizando 72 horas de teste e novamente foi realizada a leitura, conforme figura 26.

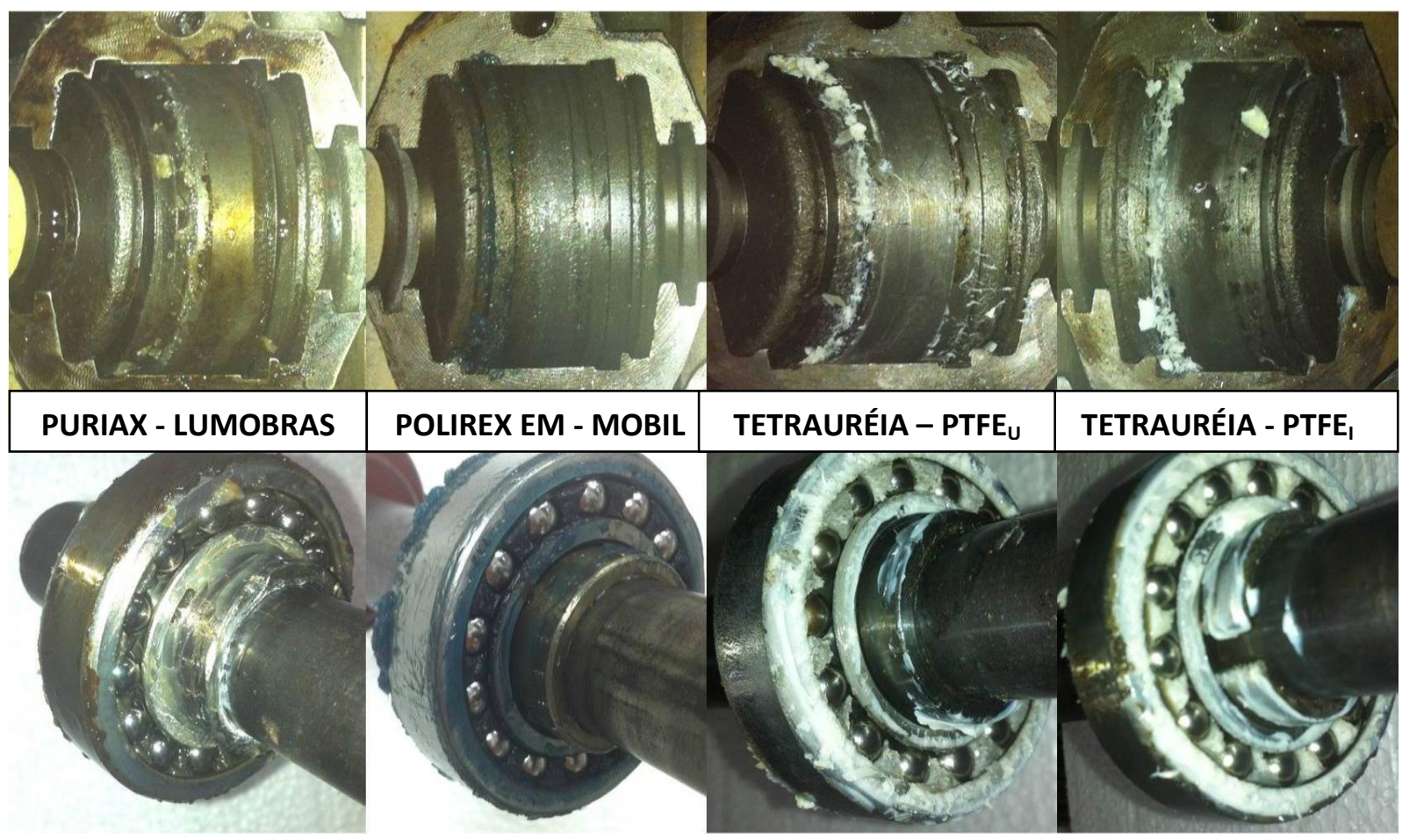

FIGURA 26 - Fotografias dos rolamentos após 72 horas de teste.

Todos os rolamentos estavam rodando facilmente, a graxa de tetrauréia com PTFE $u$ apresentou uma cor acinzentada que pode estar relacionada ao desgaste do rolamento, pois ao se desgastar, o metal libera micro cavacos que vão deixando a graxa acinzentada, a graxa da Lumobras continuou a se oxidar e foi possível notar que uma parcela do óleo escorreu para a caixa do rolamento. As

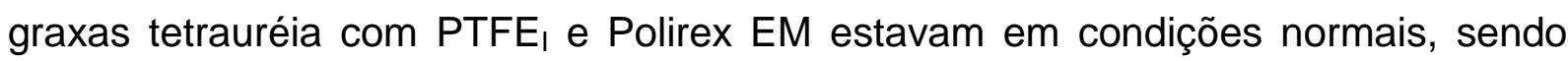
que a tetrauréia com PTFE, $_{1}$ foi a que mais se manteve aderida ao rolamento. Com esses resultados é possível afirmar que para altas temperaturas a graxa de tetrauréia aditivada com $\mathrm{PTFE}_{\mid}$substitui perfeitamente a graxa Polirex EM, sendo que a primeira adere melhor no metal, podendo ser utilizada tranquilamente em mancais de rolamentos. 


\section{CONCLUSÕES}

A síntese de tetrauréia foi bem sucedida, não necessita de catálise, e se completa em um curto período, comprovada pela espectrometria de infravermelho.

A graxa desenvolvida apresenta aspecto liso, branco e estável quando obtida em fluido de polialfaolefina com viscosidade $220 \mathrm{cSt}$ e pode ser obtida em outros veículos como demonstrado pela análise elementar.

Pela análise de quatro esferas foi possível mostrar que o excelente desempenho lubrificante e antidesgaste da graxa espessada com tetrauréia é devido à graxa trabalhar em regime de lubrificação limite, resultante da alta compatibilidade entre seu espessante tetrauréia e o fluido polialfaolefina.

A propriedade lubrificante da graxa pode ser melhorada quando adicionado pó de PTFE funcionalizado, sendo que o PTFE processado por radiação ionizante mostrou um melhor desempenho do que o processado por radiação ultravioleta, devido a sua maior oxidação, determinada por FTIR e DSC .

De acordo com as técnicas de penetração trabalhada e não trabalhada, ponto de gota, separação de óleo e teste em rolamentos este lubrificante pode ser considerado de alto desempenho e pode ser aplicado em diversos processos industriais, como motores elétricos, laminadores, cabos, entre outros. 


\section{REFERÊNCIAS BIBLIOGRÁFICAS}

Allan, M.; Maier, P; Marthaler, O.; Stadelmann, J. Emission spectra of the radical cations of difluorodiacetylene, perfluoropentadiyne 1,3, and perfluorohexadiyne2,4 in the gas phase: band systems and the lifetimes of the states. The Journal of Chemical Physics, Suiça, 17 Jul. 1978. Vol. 70, p. 5271 (1979).

AMERICAN SOCIETY FOR TESTING AND MATERIALS. Standard test methods for polyurethane raw materials: Determination of the isocyanate content of aromatic isocyanates. 1 abr. 2010. (ASTM D5155-10).

AMERICAN SOCIETY FOR TESTING AND MATERIALS. Standard test method for oil separation from lubricating grease (Conical Sieve Method). 2005. (ASTM D6184 - 98).

AMERICAN SOCIETY FOR TESTING AND MATERIALS. Standard Test Method for Measurement of Extreme-Pressure Properties of Lubricating Grease (Four-Ball Method). 2010. (ASTM D2596 - 10).

AMERICAN SOCIETY FOR TESTING AND MATERIALS. Standard Test Method for Wear Preventive Characteristics of Lubricating Grease (Four-Ball Method). 2008. (ASTM D2266 -01).

AMOCO CORPORATION. John A. Waynick. Polyurea Grease with Reduced Oil Separation. US 4759859. 29 Ago.1986, 26 jul. 1988.

Anoop Kumar, Steve Humphreys, Bill Mallory, Robust Polyurea Grease for Wide Range of Industrial Applications, Polyurea Grease, 13, p. 1-3, 2009. 
ASSOSIAÇÃO BRASILEIRA DE NORMAS TÉCNICAS. Graxa lubrificante Determinação do ponto de gota. Rio de Janeiro: ABNT NBR 6564:2009 (NBR 6564).

ASSOSIAÇÃO BRASILEIRA DE NORMAS TÉCNICAS. Graxa lubrificante Determinação da consistência pela penetração do cone. Rio de Janeiro: ABNT NBR 11345:2005 (NBR 11345).

Barbosa. C., Lubrificantes e lubrificação, apostila engenharia Mecânica - UERJ, Rio de Janeiro, Brasil, 2013.

BAYER AG. Christian Rasp, Ralf Timmermann, Hermann Perrey, Bernhard Lehmann, Siegfried Kussi. Process for the preparation of polyurea greases. US 5314982 A. 17 set. 1992, 24 mai 1994.

Bieri, G., Schmelzer, A. Fluorine and the fluoroderivatives of acetylene and diacetylene studied by $30.4 \mathrm{~nm} \mathrm{He}$ (II) photoelectron spectroscopy. The Journal of Chemical Physics, Suiça, Vol. 49, 1 July 1980, P. 213-224.

Carreteiro, R.; Belmiro, P., Lubrificantes e Lubrificação Industrial, Rio de Janeiro, 1.ed., Interciência, 2006.

Carreteiro, R.; Moura, C., Lubrificantes e Lubrificação, São Paulo, 2.ed., Makron books, 1998.

Cavicchioli, A.; Gutz, I. O uso de radiação ultravioleta para o pré-tratamento de amostras em análise inorgânica, Química nova, Vol. 26, No. 6, 913-921, 2003.

CHEVRON RESEARCH COMPANY. John L. Dreher, Richard E. Crocker. Polyureabased extreme pressure grease. US 4100081, 14 março 1977, 11 julho 1978. 
COLOMBO, M.A.S., Estudo do efeito da radiação lonizante sobre as propriedades mecânicas da poliamida 6,6. 2004. Dissertação (mestrado) - Instituto de Pesquisas Energéticas e Nucleares, São Paulo.

Cruz, A.; Souza, S., Lubrificantes e Lubrificação Industrial, São Paulo, [s.n.],1982.

D. DOWSON, M. PRIEST, G. DALMAZ, A A LUBRECHT, Tribological Research and Design for Engineering Systems. Lyon, Elsevier, 2003, p. 383-386.

Dobrowolski, J.; Kolos, R.; Sadlej, J.; Mazurek, A. Theoretical and IR-matrix isolation studies on the urea and urea- $D_{4},-C^{13}$, and $13,-{ }^{15} N_{2}$ substituted molecules. Vibrational Spectroscopy, Vol.29, 18 dez. 2001, p. 261-282 (2002).

EXXONMOBIL REASEARCH AND ENGINEERING COMPANY. Mark W. Baum. Process for preparing fine powder polyurea and greases therefrom. US 8193133 B2. 7 mar 2011, 5 jun 2012.

EXXONMOBIL REASEARCH AND ENGINEERING COMPANY. Mark W. Baum, High Viscosity Index PAO with polyurea thickeners in grease compositions. US 2009/0247441 A1. 13 fev 2009, 1 out. 2009.

EXXONMOBIL REASEARCH AND ENGINEERING COMPANY. SpectraSyn ${ }^{\text {TM }}$ Polialfaolefinas (PAO), 2003.

FERRAZ, C.C., Desenvolvimento de uma membrana nanoestruturada à base de poliacrilamida para veiculação de proteínas. 2013. Dissertação (mestrado) - Instituto de Pesquisas Energéticas e Nucleares, São Paulo.

GERALDES, A.N., Obtenção de membranas poliméricas fluoradas para o uso em células combustíveis. 2009. Dissertação (mestrado) - Instituto de Pesquisas Energéticas e Nucleares, São Paulo. 
Golimowski, J.; Golimowska, K.; Anal. Chim. Acta 1996, 325, 111.

Hironaka S. Boundary Lubrication and Lubricants. Three Bond Technical News, Tokio, 1 Jul. 1984, Vol. 9., p. 1-8 (1984).

Hissa, R., Tecnologia de Graxas Lubrificantes, Rio de Janeiro, 1.ed., Texaco Brasil, 1991.

I. Banik, S. K. Dutta, T. K. Chaki, Anil K. Bhowmick, Electron beam induced structural modification of a fluorocarbon elastomer in the presence of polyfunctional monomers, Polymer, 40, p. 447-458, 1999.

KENNETH S. KRANE, Introductory Nuclear Physics, New York: John Wiley \& sons, 1987.

Lei L.; Hongwei S., Multi-steps synthesis and properties of tetraurea grease, Industrial Lubrication and tribology, v. 63/6, p. 453-455, 2011.

Lubarsa, Manual de Lubrificação, São Paulo, Bardhal, 1970.

Moteurs, D., La Lubrification Industrielle, Paris, 2. ed., Technip, 1985.

NIPPON OIL CO. LTD. Hirotugo Kinoshita, Makoto Sekiya, Masaru Mishima. Diurea grease composition. US 5145591 A. 3 Jul. 1990, 8 set 1992.

NSK LTD., KYODO YUSHI CO. Michiharu Naka; Hideki Koizumi; Yuzo Takahashi; Koici Goto, Toshiaki Endo; Yoichi Suzuki. Grease composition for high-temperature, high-speed and high-load bearings. US 5498357 A. 27 dez. 1993, 12 março 1996.

Pires, O., Lubrificação, São Paulo, 1.ed., Mcgraw-Hill, 1975. 
Runge, P.; et al, Lubrificação Automotiva, São Paulo, Triboconcept, 1994.

SHACKELFORD, J.F.; Introduction to Materials Science for Engineers. 4th edition, Prentice Hall, USA, 1996.

SPINKS,J.W.T. WOODS,R.J. An Introduction to Radiation Chemistry. New York: Wiley-Interscience; 3 edition, 1990.

TEXACO INC. Samuel Pratt, Edward A. Fliss. Polyurea Grease Composition. US 5238589 A. 9 dez. 1992, 24 ago. 1993.

TEXACO INC. Samuel Pratt. Polyurea thickener and grease composition. US 5554586 A. 27 fev. 1995, 10 set. 1996.

THE LUBRIZOL CORPORATION. Patricia R. Todd. Polyurea-thickened grease composition. US 621778 B1. 8 ago. 2000, 10 abr. 2001.

UNIVERSITY OF COLORADO AT BOULDER - Department of Chemistry and Biochemistry. IR Spectroscopy Tutorial: Amines. Disponível em: $<$ http://orgchem.colorado.edu/Spectroscopy/irtutor/aminesir.html>. Acesso em: 18/06/2013.

Vilar, W., Química e Tecnologia dos Poliuretanos, São Paulo, Vilar consultoria, 1998. 